\title{
A Critical Analysis on Influential Factors on Power Energy Resources in China
}

\author{
Lubing Xie ${ }^{1}$, Xiaoming Rui ${ }^{1}$, Shuai $\mathrm{Li}^{1}$, Xiaozhao Fan ${ }^{2}$, Ruijing Shi ${ }^{2} \& \mathrm{Guohua} \mathrm{Li}^{3}$ \\ ${ }^{1}$ School of Energy Power and Mechanical Engineering, North China Electric Power University, Beijing, PR \\ China \\ ${ }^{2}$ College of electrical engineering, Xinjiang University, Urumqi, PR China \\ ${ }^{3}$ China Machinery Engineering Corporation, Beijing, PR China \\ Correspondence: Lubing Xie, School of Energy Power and Mechanical Engineering, North China Electric Power \\ University, Beijing, PR China. E-mail: xie_lubing@126.com
}

Received: December 19, 2017

Accepted: December 27, 2017 Online Published: January 3, 2018

doi:10.5539/mas.v12n2p1

URL: https://doi.org/10.5539/mas.v12n2p1

\begin{abstract}
China is facing a number of challenges, such as environmental pollution, energy security, and slowing down of economic growth. China's total energy consumption has been leading the worldwide consumption for several years. China's annual primary energy consumption accounts for more than $90 \%$ of total energy consumption, and the country's utilization of wind energy, solar energy, biomass energy, and other new form of energy remains very low. This research has adopted a strength, weakness, opportunity, and threat (SWOT) analysis approach to examine the internal and external factors that affect the competitiveness of the energy industry in China. An extensive and critical review of a wide range of literature was conducted, including academic papers, industry reports, statistical data, relevant regulations, and policy documents. Eighteen factors were identified from the literature review. These factors form part of an integrated framework that provides a useful tool for policy makers and the industry to gain a better understanding of the factors that affect the sustainable development of the Chinese energy industry. The results also provide a useful reference for foreign firms that intend to explore the Chinese energy industry market.
\end{abstract}

Keywords: energy industry in China, wind energy, influencing factors

\section{Introduction}

Urgent environmental problems, such as global warming, environmental deterioration, and resource depletion, are confronting countries around the world (Chang et al., 2017). China is currently facing a number of challenges, such as environmental pollution, energy security, and slowing down of economic growth (Hui et al., 2017). China has abundant energy resources. After its long-term development, China has become the largest energy producer and consumer in the world. The comprehensive development of the energy supply system of coal, electricity, oil, natural gas, new energy, renewable energy improved the technology and equipment levels of the energy industry. The living conditions of people also improved significantly.

China's energy development has attained significant achievements; however, the country is facing enormous pressure in terms of energy demand, energy supply constraints, energy production and consumption that cause ecological and environmental damage, energy technology, and the overall level of backwardness (Wang et al., 2017).

Energy is the foundation and driving force of a country's modernization; energy supply and safety are necessary for modernization construction (Jiang et al., 2017; Xinhua, 2014). Energy security is a global and strategic issue in China's economic and social development, as well as prosperity development and the improvement of people's life and social stability (Wang et al., 2017). The energy industry is one of the most complex industries in China. As a basic industry, the energy industry is closely related to the development of national economy, which is also closely related to the development of national economy (Liu et al., 2017).

The simple theory of industrial economy has failed to measure the current situation of China's energy industry. Thus, the need to establish a comprehensive evaluation system exists. The new energy evaluation system is 
reconstructed. The evaluation index is divided into 18 dimensions, which cover the macro level of population, gross domestic product (GDP), urbanization, international economic environment, energy supply and consumption, and the performance of various energy sectors.

A number of internal and external factors affect the sustainable development of the energy industry in China. This situation calls for a comprehensive analysis of the industry to highlight these factors and to provide useful inputs to government authorities and private developers.

\section{Research Methodology}

A strength, weakness, opportunity, and threat (SWOT) approach was employed to identify the factors that affect the competitiveness of the energy industry in China (Hui et al., 2017; Jaber et al., 2015). SWOT analysis has been widely adopted in strategic management studies to highlight internal and external factors in the sustainable development of an industry or organization (Hui et al., 2017; Jaber et al., 2015). The use of SWOT analysis will facilitate the development of strategies aimed at improving and sustaining the competitiveness of energy enterprises. The research procedure and methodology used in this paper is shown in Fig. 1.

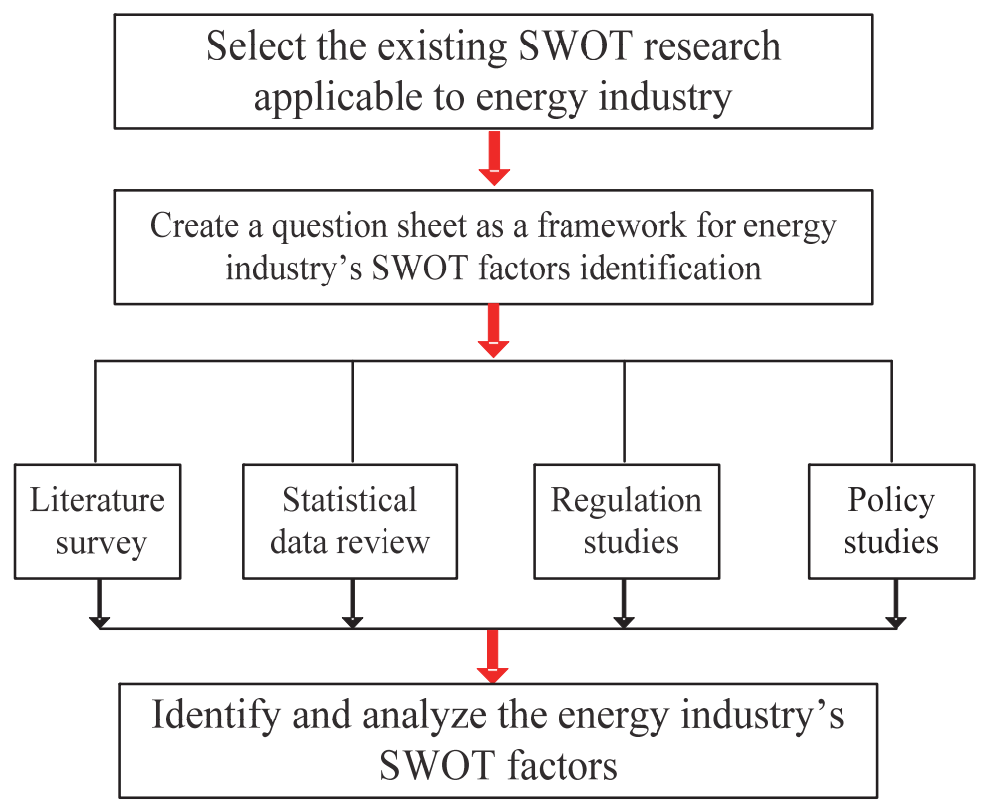

Figure 1. Research procedure and methodology

The initial question sheet used to establish a framework for the SWOT analysis covered the following questions (Hui et al., 2017; Jaber et al., 2015; Zhou et al., 2015):

(1) What are the strengths and weaknesses associated with the energy industry in China?

(2) What are the development and future of all kinds of energy sources, including renewable energy and conventional fossil fuels?

(3) What are the barriers to the development of the energy industry in China?

(4)Are there any critical issues associated with the current energy industry development in China?

(5) Are there external factors, either positive or negative, that affect the sustainable development of the Chinese energy industry?

(6) What is the future of the Chinese energy industry?

A multifaceted qualitative research approach was adopted to study the Chinese energy industry. This approach reviews and retrieves evidence and information from various resources, such as official statistics, academic literature, policies, and regulations [2].

\subsection{Literature Survey}

An extensive literature survey was conducted to review the latest research (i.e., published between 2010 and 2015) related to the energy industry in china. These studies include top international journals, such as Energy, Renewable and Sustainable Energy Reviews, Journal of Power Sources, Progress in Photovoltaics Energy Policy, 
Renewable Energy. This study also includes high-impact Chinese journals, including Proceedings of the CSEE, Renewable Energy Resources, Power System Technology Academic Journal, Automation of Electric Power Systems Academic Journal, Energy Technology and Economics, Power Equipment, Energy of China.

\subsection{Statistical Data Review}

The official statistics provide references for analyzing the SWOT factors of the energy industry in China. The statistical data adopted in this research are primarily derived from the United Nations, the United Nations Development Programme (UNDP), the U.S. Central Intelligence Agency, the International Monetary Fund (IMF), the World Bank (WB), BP Company, International Energy Agency, National Energy Administration, China Renewable Energy Association, Legatum Institute, the European Commission, Wikipedia, World Nuclear Association (WNA), REN21, and the China National Bureau of Statistics.

\subsection{Regulation Studies}

Relevant regulations and laws supply important information that can be used to explore the SWOT factors of the energy industry in China. These regulations include the Renewable Energy Regulations (NDRC 2005), China Energy Law (Tsinghua University, 2008), Energy Development Strategy Action Plan (2014-2020) (General Office of the State Council, 2014), Energy Industry Strengthen Air Pollution Control Work Programme (National Development and Reform Commission, 2014), and the New National Energy Commission.

\subsection{Policy Studies}

National policies also play a critical role in the sustainable development of the energy industry in China. The policies reviewed in this research include various official regulations and reports published by major authorities, such as the Energy Conservation Law of China (Standing Committee of the National People's Congress, 2005), Renewable Energy Law (Standing Committee of the National People's Congress, 2006), Interim Measures for the Project Operation Management under the Clean Development Mechanism (NDRC, 2011), the Twelfth Five-Year National Energy Planning (National Energy Administration, 2011) and the Thirteenth Five-Year National Energy Planning (National Energy Administration, 2015).

\section{Analysis of the Energy Industry in China}

The internal and external factors were identified by conducting a critical analysis of the Chinese energy industry, which is shown in Fig. 2. Each factor was analyzed and discussed in the following sections (Hossain et al., 2015; Zhou \& Yang, 2015).

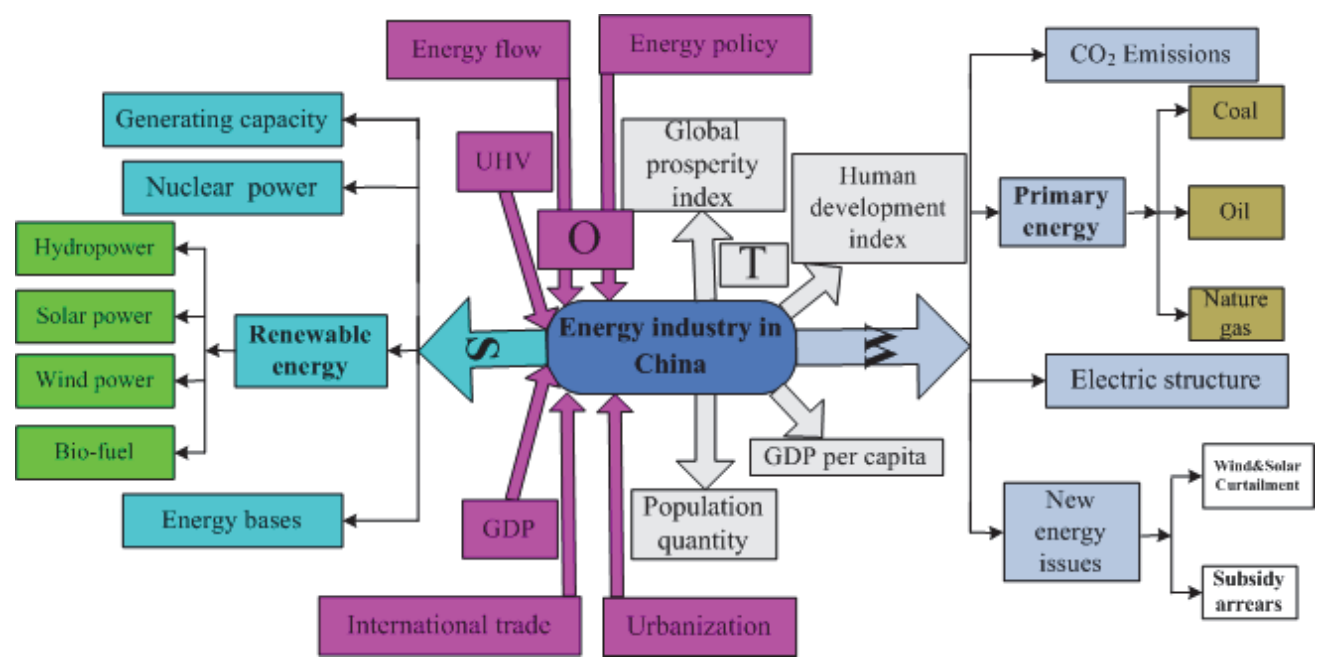

Figure 2. Structure of influence factors for China's energy industry

\subsection{Analysis of Strength Factors}

\subsubsection{Generating Csapacity}

According to BP's Statistical Review of World Energy 2015, China is the world's largest producer of electricity contributing $24 \%$ of global production, followed by the United States, India and Japan (Table 1) (Petroleum, 2015) (Note 1).

Table 1. Generating capacity of the main countries in the world. Unit: TWh $(109 \mathrm{kWh})$ 


\begin{tabular}{cccccc}
\hline Time & 2012 & 2013 & 2014 & Growth rate & $\begin{array}{c}\text { Proportion of } \\
\text { total (2014) }\end{array}$ \\
\hline China & $\mathbf{4 9 8 7 . 6}$ & $\mathbf{5 4 3 1 . 6}$ & $\mathbf{5 6 4 8 . 9}$ & $\mathbf{4 \%}$ & $\mathbf{2 4 \%}$ \\
USA & 4249.1 & 4268.5 & 4298.4 & $0.7 \%$ & $18.3 \%$ \\
India & 1053.9 & 1102.8 & 1208.7 & $9.6 \%$ & $5.1 \%$ \\
Japan & 1106.9 & 1087.8 & 1061.7 & $-2.4 \%$ & $4.5 \%$ \\
\hline
\end{tabular}

\subsubsection{Nuclear Energy Power Generation}

According to the report of World Nuclear Association (WNA) (Note 2), nuclear power generation accounted for $11.5 \%$ of the total power generation in 2014 , but China accounted for only $2.4 \%$. In June 2015 , the running reactors of nuclear power around the world were 437, wherein China accounted for 26 seats; this number was inferior to France, the United States, Japan, and Russia; however, as shown in Table 2, the number of nuclear power generation reactors being constructed in China is higher than that in any other country across the world (Zhou \& Yang, 2015).

Table 2. Nuclear power in the world

\begin{tabular}{llllllllllll}
\hline & \multicolumn{3}{l}{$\begin{array}{l}2014 \\
\text { Country }\end{array}$} & $\begin{array}{l}\text { Nuclear } \\
\text { power }\end{array}$ & \multicolumn{3}{l}{ June 2015 } & \multicolumn{3}{l}{ Operation } & \multicolumn{2}{l}{$\begin{array}{l}\text { Under } \\
\text { construction }\end{array}$} & \multicolumn{2}{c}{ Approved } & Pre-planned & \multicolumn{2}{l}{$\begin{array}{l}\text { Uranium } \\
\text { demand }\end{array}$} \\
& TWh & $\%$ & No. & MW & No. & MW & No. & MW & No. & MW & Tons U \\
\hline France & 418 & 76.9 & 58 & 63130 & 1 & 1720 & 1 & 1720 & 1 & 1100 & 9230 \\
USA & 799 & 19.5 & 99 & 98792 & 5 & 6018 & 5 & 6063 & 17 & 26000 & 18692 \\
Japan & 0 & 0 & 43 & 43480 & 3 & 3036 & 9 & 12947 & 3 & 4145 & 2549 \\
Russia & 169 & 18.6 & 34 & 25264 & 9 & 7968 & 31 & 33264 & 18 & 16000 & 4206 \\
China & $\mathbf{1 2 4}$ & $\mathbf{2 . 4}$ & $\mathbf{2 6}$ & $\mathbf{2 3 1 4 4}$ & $\mathbf{2 4}$ & $\mathbf{2 6 3 1 3}$ & $\mathbf{4 4}$ & $\mathbf{5 1 0 5 0}$ & $\mathbf{1 3 6}$ & $\mathbf{1 5 3 0 0 0}$ & $\mathbf{8 1 6 1}$ \\
World $^{* *}$ & 2411 & 11.5 & 437 & 380250 & 66 & 68997 & 168 & 189504 & 322 & 364270 & 66883 \\
\hline
\end{tabular}

Note. **The world total includes 6 reactors in Taiwan, China. The production capacity is $4927 \mathrm{MW}$, in 2014 the production was $40.8 \mathrm{TWh}$ (estimated to account for $18.9 \%$ of Taiwan electric power production). Taiwan has two reactors under construction, the production capacity is $2700 \mathrm{MW}$. Estimated 972 tons of uranium demand in 2015.

\subsubsection{Renewable Energy}

According to the United Nations Economic Commission for Europe (UNECE), the Renewable Energy Policy Network for the 21st Century, and the 2015 report of REN21, a 21st century renewable energy policy network, global renewable energy accounted for $22.8 \%$ of the total power by the end of 2014; hydropower was highest at $16.6 \%$, followed by wind power, which accounted for $3.1 \%$ (Note 3). Fig. 3 shows the ratio of global renewable energy to electricity production.

According to Wikipedia, China's renewable energy generation ranked first in the world in June 2015, but the power structure is not high; Chinese renewable energy accounted for about $20 \%$ (Zhao et al., 2015) (Note 4). Table 3 and Fig. 4 show the renewable energy generation of major countries and regional organizations across the world (Petroleum, 2015).

Table 3. Top 10 renewable energy generation countries in the world (annual TWh)

\begin{tabular}{lllllllll} 
Rank & Country & Time & Total & Hydropower & $\begin{array}{l}\text { Wind } \\
\text { power }\end{array}$ & $\begin{array}{l}\text { Biomass } \\
\text { power }\end{array}$ & $\begin{array}{l}\text { Solar } \\
\text { power }\end{array}$ & $\begin{array}{l}\text { Geothermal } \\
\text { power }\end{array}$ \\
\hline $\mathbf{1}$ & China & $\mathbf{2 0 1 4}$ & $\mathbf{1 3 0 0}$ & $\mathbf{1 0 6 6}$ & $\mathbf{1 6 0}$ & $\mathbf{4 2}$ & $\mathbf{2 8 . 2}$ & -- \\
& EU & 2013 & 755.7 & 395.5 & 227.4 & 51.3 & 75.6 & 5.9 \\
2 & USA & 2012 & 508.4 & 276.2 & 140.8 & 71.4 & 4.3 & 15.6 \\
3 & Brazil & 2012 & 451.5 & 411.2 & 5 & 35.3 & -- & -- \\
4 & Canada & 2012 & 397.3 & 376.7 & 11.3 & 9 & 0.4 & - \\
5 & Russia & 2012 & 167.9 & 164.4 & -- & 3 & -- & 0.5 \\
6 & India & 2012 & 160 & 124.4 & 28.3 & 5 & 2 & --
\end{tabular}




\begin{tabular}{lllllllll}
7 & Norway & 2012 & 142.4 & 140.5 & 1.6 & 0.4 & -- & -- \\
8 & Germany & 2013 & 131.6 & 28.6 & 51.7 & 20.2 & 31 & -- \\
9 & Japan & 2012 & 122.4 & 74.4 & 4.8 & 33.2 & 7 & 2.6 \\
10 & Spain & 2013 & 107 & 39.8 & 53.9 & 0.6 & 12.7 & -- \\
\hline
\end{tabular}

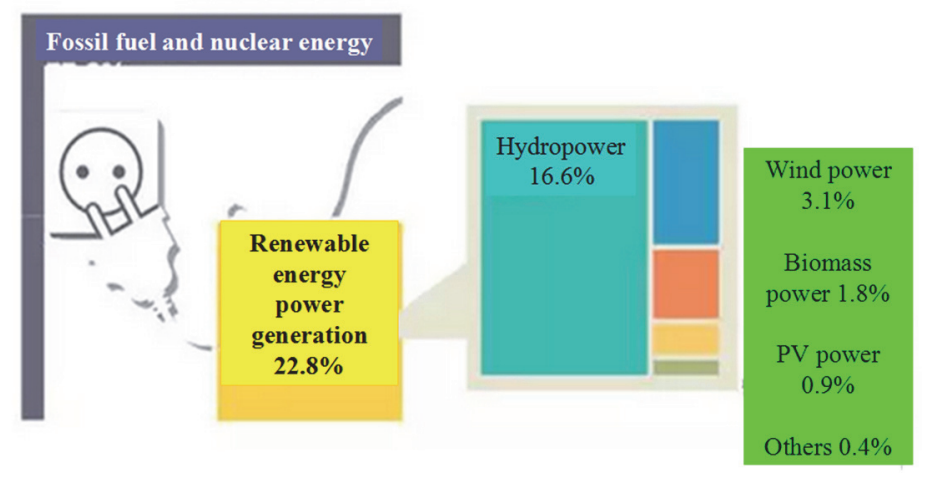

Figure 3. Global renewable energy accounted for the ratio of electricity production

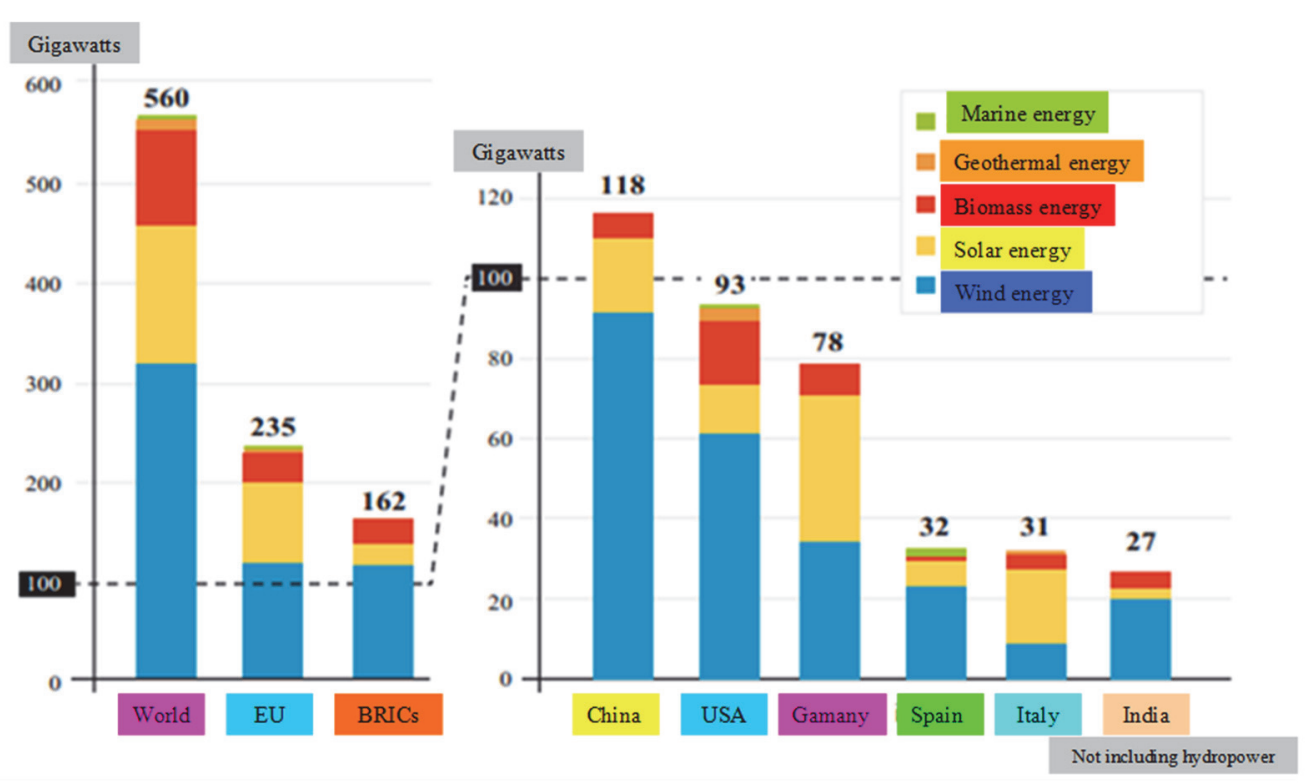

Figure 4. Renewable energy generation in main countries and regional organizations

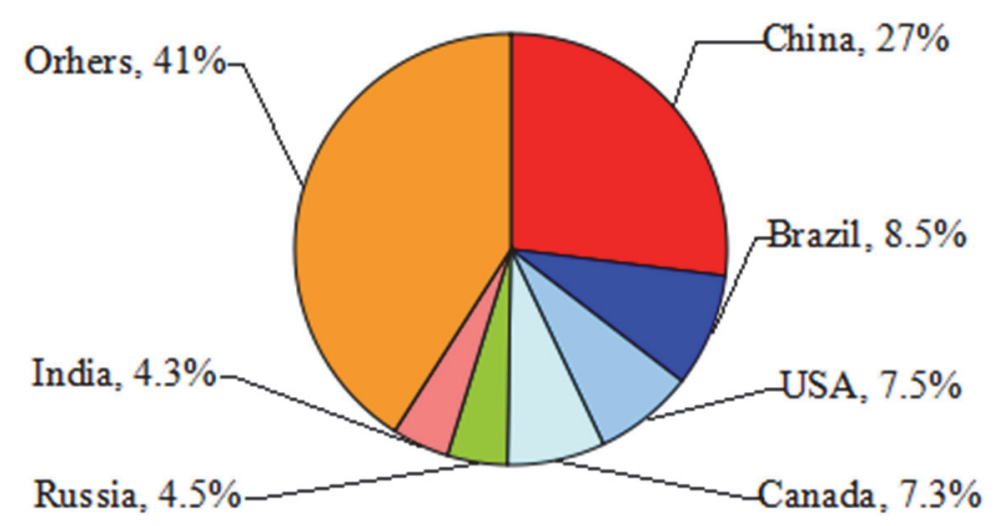

Figure 5. Largest share of the country's hydropower in 2014

Hydropower 
According to REN21 2015 report, the global hydropower production capacity in 2014 reached $1055 \mathrm{GW}$, of which China was the largest contributor at 27\%, as shown in Fig. 5 (Note 3).

According to BP's Statistical Review of World Energy 2015, although China's hydropower ranks first in the world, hydropower is only $8.1 \%$ of China's energy consumption; several countries rank higher than China, as shown in Table 4 (Petroleum, 2015; Li et al., 2015; Li et al., 2015).

Table 4. Hydropower proportion of the main countries in 2014

\begin{tabular}{ccccccccc}
\hline Country & China & Norway & Switzerland & Sweden & Brazil & $\begin{array}{c}\text { New } \\
\text { Zealand }\end{array}$ & Columbia & Canada \\
\hline $\begin{array}{c}\text { Hydropower } \\
\text { proportion }\end{array}$ & $\mathbf{8 . 1 \%}$ & $66.2 \%$ & $29.6 \%$ & $28.3 \%$ & $28.2 \%$ & $26.4 \%$ & $26.0 \%$ & $25.6 \%$ \\
\hline
\end{tabular}

Solar water heater

According to REN21 report in 2015, the global solar water heater capacity in 2014 was 406, wherein China accounted for about 70\%, which was equivalent to $284.2 \mathrm{GW}$ th, as shown in Fig. 6 (Qiu et al., 2015) (Note 3).

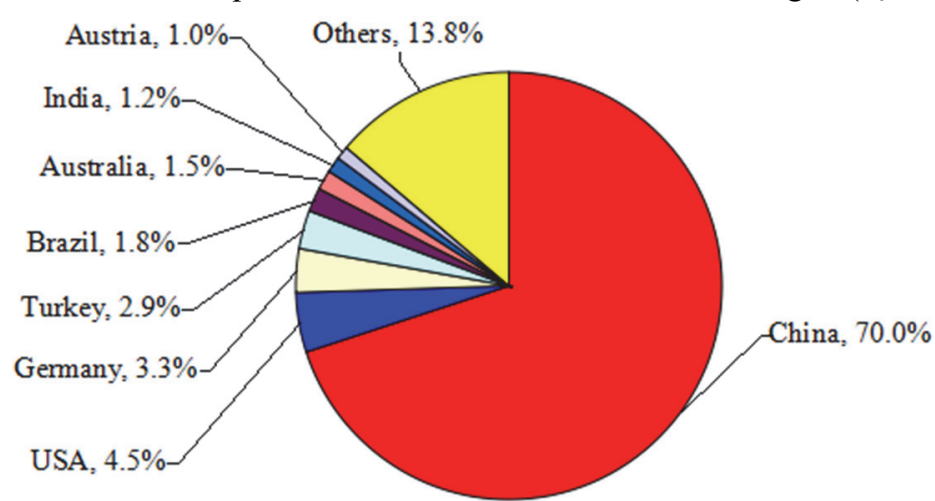

Figure 6. Solar water heater capacity of the main countries in 2014

Given that $106 \mathrm{~m} 2$ solar water heater amounts to $0.7 \mathrm{GWth}, 1 \mathrm{GW}$ th amounts to $1.43 \times 106 \mathrm{~m} 2$ solar water heater. Thus, the area installed by China's solar water heater is given as (Qiu et al., 2015):

$$
284.2 \times 1.43 \times 106 \mathrm{~m} 2=403.6 \times 106 \mathrm{~m} 2 \approx 4 \text { million } \mathrm{m} 2 .
$$

Solar power generation

According to BP's Statistical Review of World Energy 2015, China's use of solar power ranks second place worldwide, which accounts for $15.7 \%$ of the world's total, second only to Germany, as shown in Table 5 (Petroleum, 2015; Lee et al., 2014) (Note 1).

Table 5. Countries with the largest global solar power production (TWh)

\begin{tabular}{ccccc}
\hline Country & 2013 & 2014 & Growth rate $\%$ & Proportion \\
\hline Germany & 31.0 & 34.9 & 12.6 & 18.8 \\
China & 15.5 & 29.1 & 87.6 & 15.7 \\
Italy & 21.6 & 23.7 & 9.7 & 12.7 \\
Japan & 10.6 & 19.4 & 82.4 & 10.4 \\
USA & 9.1 & 18.5 & 102.8 & 10.0 \\
Others & 46.7 & 60.3 & -- & 32.4 \\
The world & 134.5 & 185.9 & 38.2 & 100 \\
\hline
\end{tabular}

Photovoltaic power generation capacity.

According to BP Statistical Review of World Energy 2015, China's installed PV capacity ranks second in the world, which accounts for $15.6 \%$ of the world's total, second only to Germany, as shown in Table 6 (Petroleum, 2015; Hosenuzzaman et al., 2015). 
Table 6. Cumulative installed capacity of photovoltaic power generation

\begin{tabular}{ccccc}
\hline Time & 2013 & 2014 & Growth rate \% & Proportion \% \\
\hline Germany & 36300 & 38200 & 5.2 & 21.2 \\
China & 17639 & 28199 & 59.9 & 15.6 \\
Italy & 18074 & 18460 & 2.1 & 10.2 \\
Japan & 13500 & 23300 & 71.3 & 12.9 \\
USA & 12079 & 18280 & 51.3 & 10.1 \\
Others & 42558 & 53957 & -- & 30 \\
The world & 140150 & 180396 & 28.7 & 100 \\
\hline
\end{tabular}

Wind power generation capacity

According to BP Statistical Review of World Energy 2015, China's wind farm power generation ranks second in the world, which accounts for $22.4 \%$ of the total, next to the United states, as shown in Table 7 (Petroleum, 2015; Sun et al., 2015).

Table 7. Wind farm power generation in main countries (TWh)

\begin{tabular}{ccccc}
\hline Time & 2013 & 2014 & Growth rate\% & Proportion \% \\
\hline USA & 169.5 & 183.6 & 8.3 & 26.0 \\
China & 141.2 & 158.4 & 12.2 & 22.4 \\
Germany & 51.7 & 56.0 & 8.2 & 7.9 \\
Spain & 53.9 & 52.3 & -3.0 & 7.4 \\
England & 28.4 & 31.6 & 11.2 & 4.5 \\
Others & 196 & 224.3 & -- & 31.8 \\
The world & 640.7 & 706.2 & 10.2 & 100 \\
\hline
\end{tabular}

Wind power installed capacity

According to World Wind Energy Association (WWEA), the total global capacity for installed wind power reached $392927 \mathrm{MW}$ in June 2015 (Note 5) (Note 6). The newly installed capacity reached $21678 \mathrm{MW}$, which is equivalent to an increase of 5.8\% from $17600 \mathrm{MW}$ in 2014 and $13900 \mathrm{MW}$ in 2013. As of the first half of 2015, wind power met $4 \%$ of the world's electricity demand. Global capacity for installed wind power is shown in Fig. 7. However, in recent years, the situation of wind power abandonment in China is very serious, and the wind power construction in Liaoning, Jilin, Heilongjiang, Ningxia, Gansu, Yunnan and Guizhou has been completely stagnant. In some areas of China, the trend of wind power curtailment is rising and getting worse. In 2016, the total wind power curtailment in China reached 49 billion and 700 million kWh, 4 times as much as in 2014.Wind power curtailment in major provinces of China from 2012 to 2013 can be seen from Fig.8.

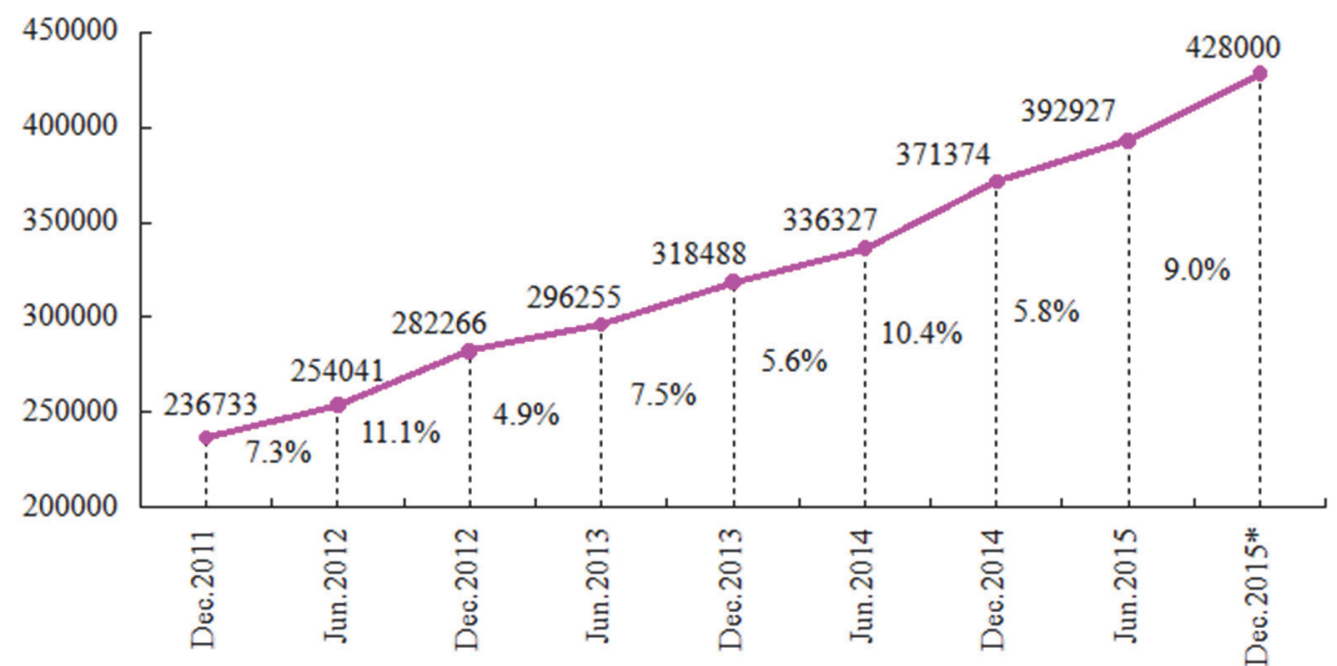

Figure 7. Global wind power installed capacity(*Expected by WWEA) 


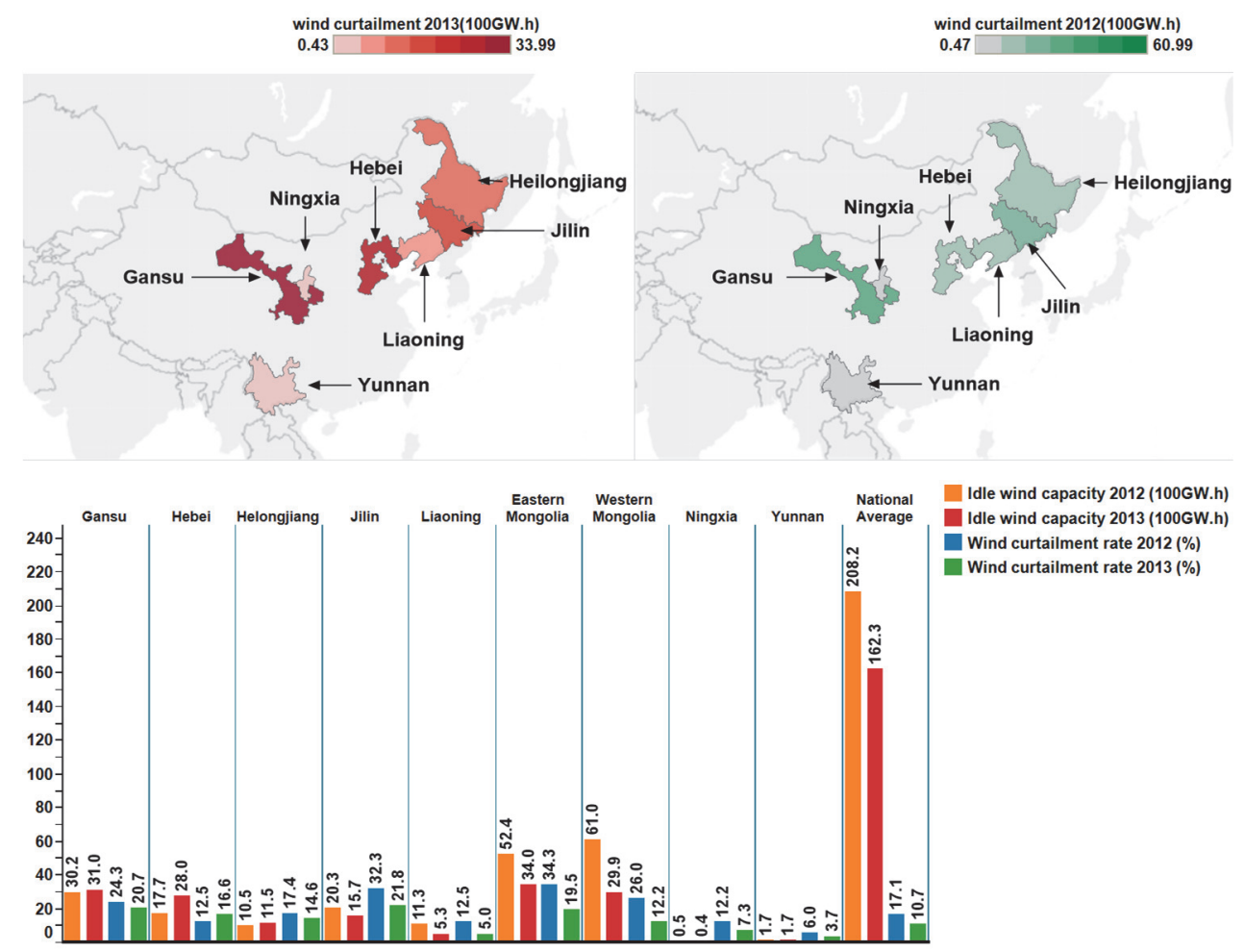

Figure 8. Wind power curtailment in major provinces of China from 2012 to 2013

According to BP Statistical Review of World Energy 2015, the capacity for installed wind farm in China ranks first in the world, which accounts for $30.7 \%$ of the total (Petroleum, 2015). Installed wind power capacity of major countries across the world is shown in Table 8.

Table 8 . Wind power installed capacity of the main countries in the world(MW)

\begin{tabular}{ccccc}
\hline Time & 2013 & 2014 & Growth rate \% & Proportion $\%$ \\
\hline China & 91413 & 114609 & 25.4 & 30.7 \\
USA & 61292 & 66146 & 7.9 & 17.7 \\
Germany & 34700 & 40500 & 16.7 & 10.9 \\
Spain & 22898 & 22987 & 0.4 & 6.2 \\
India & 20150 & 22465 & 11.5 & 6 \\
Others & 90491 & 106254 & -- & 28.5 \\
The world & 320944 & 372961 & 16.2 & 100 \\
\hline
\end{tabular}

Compared with the onshore wind power, offshore wind farm has the average wind speed is high, the number of hours in high, and with China's renewable energy development plan "in 13th Five-Year" the introduction of offshore wind power has been showing a new pattern of steady development in recent years. There are several analysis assessing the potential of China offshore wind energy. At the end of 2009, China Meteorological Administration proposed a wind assessment, based on measurements at $50 \mathrm{~m}$ height, showing that China has a potential to develop $200 \mathrm{GW}$ of class 3 wind power. Another research carried out by the UNEP in cooperation with the US National Renewable Energy Laboratory (NREL), calculated the exploitable offshore wind resource of 600GW. The newest estimation by WWF, China Wind Energy Association and Sun Yet-sen University shows the total technical potential of China along the entire coast from Liaoning to Hainan is 11,580 TWh/year.

The Offshore area has been divided into different classes depending on the distance from the coastline, specifically area less than $10 \mathrm{~km}$ from the coast, areas 10-30 km away, areas 30-60 km away and areas more than $60 \mathrm{~km}$ away. Owing to the long and winding coastal line, China has rich offshore wind energy resources, in particular on the south-east coast and nearby islands including Shanghai, Tianjin and the provinces of Shandong, 
Liaoning, Jiangsu, Zhejiang, Fujian, Guangdong, Guangxi, Hebei and Hainan. The annual wind power density reaches above $200 \mathrm{~W} / \mathrm{m} 2$ within the areas $10 \mathrm{~km}$ from the coast, and frequently exceeds $500 \mathrm{~W} / \mathrm{m} 2$ on the adjacent islands, such as Tai Mountain, Pingtan, Dongshan, Nanlu, Dachen, Shengsi, Nanao, Mazu, Magong and Dongsha. Xia Changliang, Song Zhanfeng. Wind energy in China: current scenario and future perspectives. Renewable and Sustainable Energy Reviews 2009,13:1966-1974. In fact, the majority of Chinese offshore projects are installed in the shallow waters close to the shore, called inter-tidal projects, where the sites dry out (or nearly so) at low tide. Most of the projects in deeper waters, such as those granted under the first round of tenders, are either still in development or have just started construction due to the high construction cost in comparison to onshore project. Figure 5 and Figure 6 presents the scenario of Jiangsu Rudong Longyuan inter-tidal project at high tide and low tide respectively. Moreover, the latest wind energy mapping of coastal zones released by CMA shows that the highest wind speed was mainly found in the South Sea, especially for the coastline along Fujian Province and the Taiwan Strait. Figure 7 shows their recent result of China's offshore wind speed, $70 \mathrm{~m}$ within $100 \mathrm{~km}$ at the water depth of $5 \mathrm{~m}, 25 \mathrm{~m}$ and $50 \mathrm{~m}$ respectively. According to the China Wind Energy Association (CWEA) data statistics, in 2016, China's offshore wind power installed 154 new units, the new capacity of $590 \mathrm{MW}$, the total installed capacity reached $1.63 \mathrm{GW}$, an increase of $64 \%$. In all the lifting of the offshore wind turbine, the unit capacity for $4 \mathrm{MW}$ was the largest, the cumulative installed capacity reached $740 \mathrm{MW}$, accounting for $45.5 \%$ of the total installed capacity, followed by a single $3 \mathrm{MW}$ accounted for $14 \%$ of total installed capacity. In August 2017, the largest wind turbine 5MW offshore wind turbine (China Sea Loading H171-5MW) was successfully hoisted in Rudong, Jiangsu, as shown in Figure 3, which indicates that the capacity of offshore wind power in China has entered a new stage of development. In the past decade, the global offshore wind power is developing rapidly. In 2016 the global offshore wind power added 2.19GW new installed capacity, the total installed capacity accumulated $14.38 \mathrm{GW}$, and China's offshore wind power behind Britain and Germany, ranked third in the world. In order to realize the global offshore wind power installed capacity of 40GW and China's "13th Five-Year" plan of offshore wind power installed capacity of more than $5000 \mathrm{MW}$ in 2020 , China's offshore wind turbine operation and maintenance has become has become a very urgent and urgent problem for offshore wind power industry development.

Bio-fuel

According to BP Statistical Review of World Energy 2015, the bio-fuel development of China is slow, which ranks seventh worldwide. By contrast, countries such as Argentina and Indonesia have rapid bio-fuel development, as shown in Table 9 (Petroleum, 2015) (Note 1).

Table 9. Countries with the largest global bio-fuel production

\begin{tabular}{lcccc}
\hline Country & 2013 & 2014 & Growth rate \% & Proportion \\
\hline U.S.A & 28462 & 30056 & 5.6 & 42.5 \\
Brazil & 15782 & 16656 & 5.5 & 23.5 \\
Germany & 2632 & 2684 & 2.0 & 3.8 \\
Argentina & 1970 & 2577 & 30.9 & 3.6 \\
Indonesia & 1740 & 2444 & 40.4 & 3.5 \\
France & 2220 & 2269 & 2.2 & 3.2 \\
China & 2016 & 2083 & 3.3 & 2.9 \\
Others & 11106 & 12023 & -- & 17 \\
The world & 65928 & 70792 & 7.4 & 100 \\
\hline
\end{tabular}

\subsubsection{Energy Bases in China}

On January 1, 2013, China issued the 12th Five-Year Energy Development Plan, which proposed the establishment of five comprehensive energy bases in Xinjiang Province, Eastern Inner Mongolia, Ordos Basin, Shanxi Province, and Southwest China. This plan is illustrated in Fig. 9. Comprehensive energy includes thermal power and renewable and sustainable energy (Note 6) (Fan et al., 2015). Hami District in Xinjiang Province has plenty of coal resources that are of good quality. These coal resources are buried in shallow areas with centralized distribution. As one of the tens of millions kilowatt wind power bases, it can develop large-scale thermal power and renewable energy power units, such as wind power units. Energy is widely distributed in China, but this distribution is unbalanced. Coal resources are distributed in north and northwest areas, whereas hydropower resources are found in the southwest zone. Oil and natural gas are concentrated in the eastern, middle, western, and coastal regions. Main energy consumption occurs in the southeast coastal area, where the 
economy is quite developed. These distribution patterns show that energy consumption and energy storage are unbalanced (Zeng et al., 2014; Zhang \& Qiping, 2013). In China, large-scale and long-distance coal, oil, gas, and electric power transported from resource-rich areas to high-demand areas will last for a long time. As shown in Fig. 5, the five comprehensive energy bases will produce 2.66 billion tons of standard coal in 2015, which constitutes $70 \%$ of the total yield; this primary energy will be exported to other areas as 1.37 billion tons of standard coal, which constitutes $90 \%$ of the total yield of regional transportation energy (Jie et al., 2015).

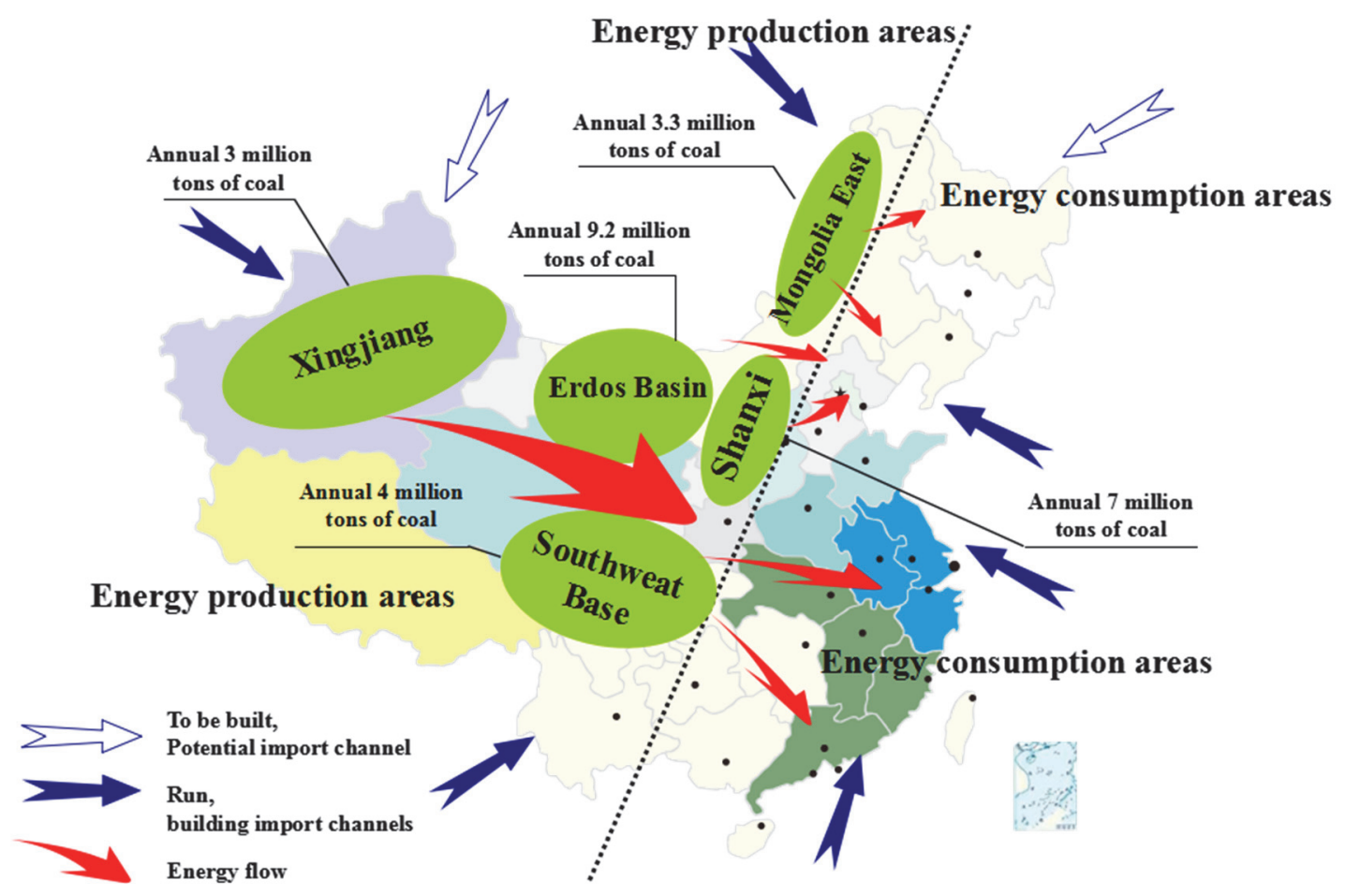

Figure 9. Five comprehensive energy bases in China

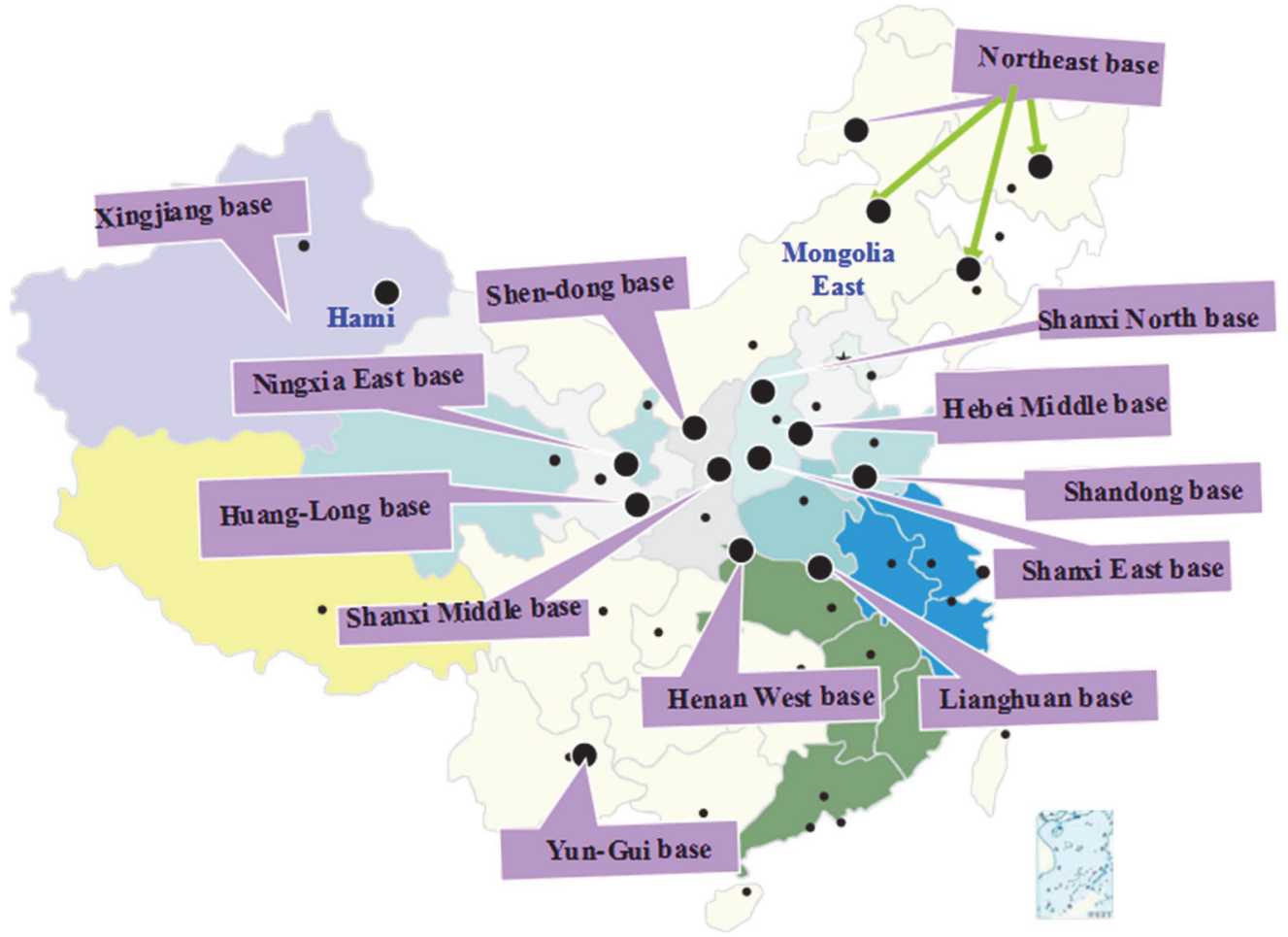

Figure 10. 14 coal bases in China 
Chinese-proven coal resources include $12 \%$ lignite, $10 \%$ anthracite, and $78 \%$ soft coal. Of these energy sources, $50 \%$ of soft coal is low-rank coal, $5 \%$ is high-rank coal, and $23 \%$ is mid-rank coal. Fig. 10 shows the 14 large-scale coal bases in China. In accordance with the 12th Five-year Energy Development Plan, China intends to accelerate the construction of coal bases in the northern area of Shaanxi Province, Huanglong, Shendong, eastern area of Inner Mongolia, eastern area of Ningxia Province, and Xinjiang Province (Note 7) (Yang et al., 2015). The plan aims to optimize the exploitation of coal resources in the northern-middle-eastern area of Shanxi Province, Henan Province, cities around the Huaihe River, Yunnan, and Guizhou Province. At the end of the 12th Five-year Plan, 10 Chinese companies will own more than 100 million tons of coal resources and another 10 companies will be processing more than 5 billion tons of coal resources. The coal produced by these companies will constitute $60 \%$ of the total coal production in China (Dzonzi-Undi \& Li, 2015; Sun et al., 2015).

As shown in Fig. 11, the present 13 large hydropower bases in China have been formed (Zhao et al., 2012; Ming et al., 2013) (Note 8). During the 13th Five-Year Plan, the installed hydropower capacity of China is expected to concentrate on hydropower bases, such as the Jinshajiang River, Lancang River, and Nujiang River, where the development level is relatively low at present. The development level of these hydropower bases is expected to soar to $54.8 \%, 76.6 \%$, and $33.6 \%$, respectively. The total development level of hydropower bases is about $70.3 \%$. The focus of hydropower construction will gradually shift to Tibet and Xinjiang. Tibet will be the latest hydropower base in the 14th and 15th Five-Year Plan. Overall, the large hydropower bases in China will be constructed during the 12th and 13th Five-Year Plans. By 2020, the installed hydropower capacity in Tibet will reach 2 million $\mathrm{kW}$ and its development level will increase to 1.5\% (Ming et al., 2013; Lin \& Li, 2015).

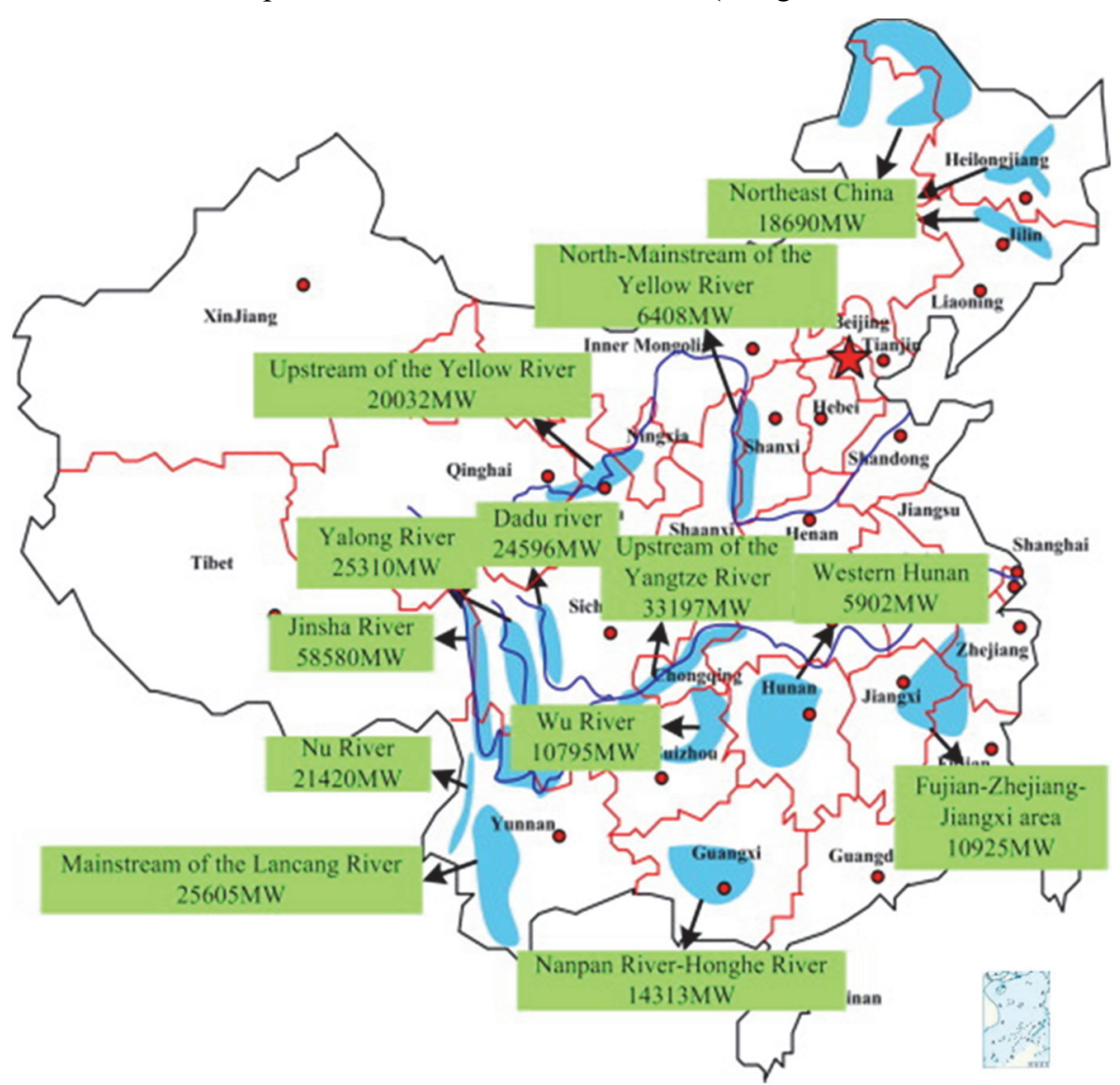

Figure 11. 13 hydropower bases in China (Zhao et al., 2012; Ming et al., 2013) (Note 8)

According to China's wind resource distribution, the layout of the wind power bases in Hami in Xinjiang and Jiuquan in Gansu is based on the program "Building a large base, connect into the big power grid;" given China's focus on the development of nine 10 million $\mathrm{kW}$ class wind power base (Fig. 12) and nine large wind farms, the country's installed capacity is expected to reach more than $79 \mathrm{GW}$ in late 2015 , which will account for more than 75\% of China's total wind power (Hosenuzzaman et al., 2015; Ming et al., 2013; Lin \& Li, 2015; (Wu \& Sun, 2015) (Note 9). 


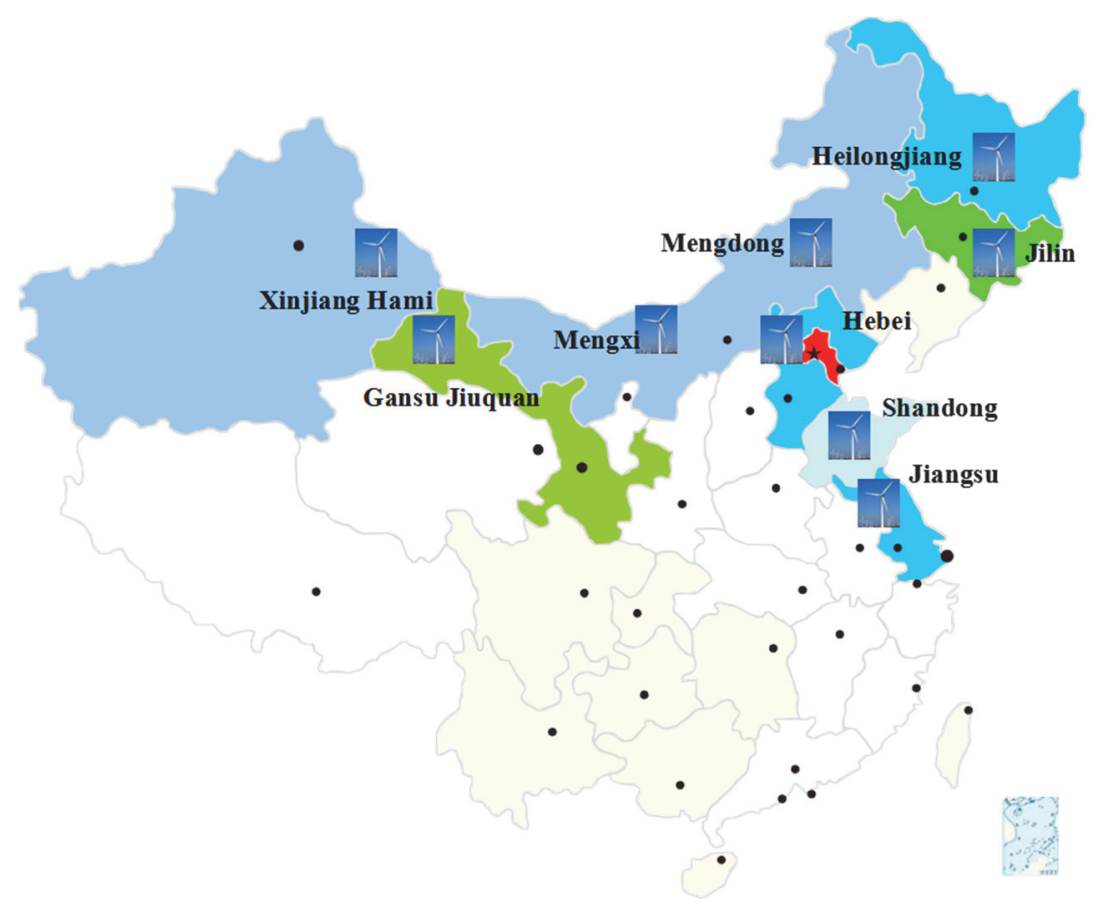

Figure 12. 13 wind power bases in China

Statistics from the National Energy Bureau indicate that the PV power of China reached 35780 MW in June 2015. The distributed installed PV capacity of $5710 \mathrm{MW}$ and installed photovoltaic power station capacity of 30070 MW accounting for $84.04 \%$ of the total. In the first half of 2015 , the installed PV national capacity was $7730 \mathrm{MW}$; this figure comprises the distributed installed photovoltaic capacity of $1040 \mathrm{MW}$, which accounts for $13.45 \%$ of total PV power; the installed power station capacity of $6690 \mathrm{MW}$ accounts for $86.55 \%$. National Energy Administration. (2015).

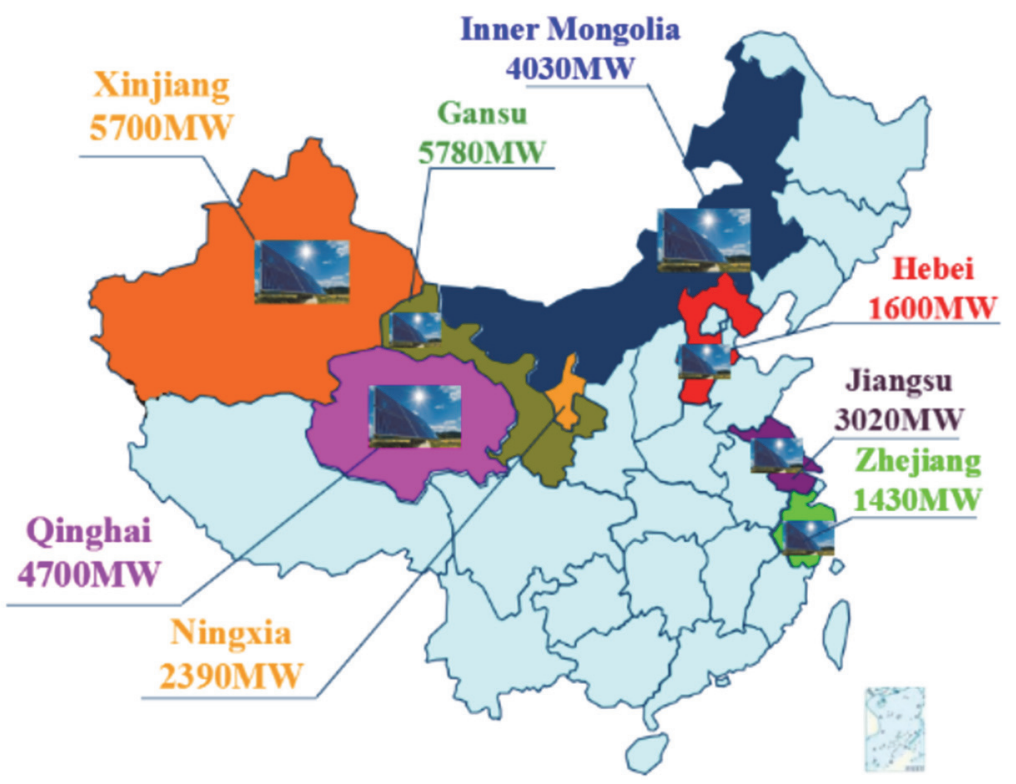

Figure 13. 8 provinces' PV power scale in more than 1000MW

As shown in Fig. 13, Chinese provinces, which are composed of autonomous regions and municipalities, have 8 PV power stations with installed capacity of more than $1000 \mathrm{MW}$. The new installed capacity of the main provinces in the first half of 2015 is shown in Fig. 13. 
As shown in Fig. 12, the installed PV capacity in Xinjiang reached 5700 MW in June 2015, which was next to Gansu's 5780 MW capacity. Gansu's installed PV capacity ranks second in the country and accounts for 15.93. National Energy Administration. (2015). Fig. 14 shows that the new installed PV capacity in Xinjiang reached $2140 \mathrm{MW}$, which ranks first in the country and accounts for $27.65 \%$ of the new installed national capacity in the first half of 2015 .

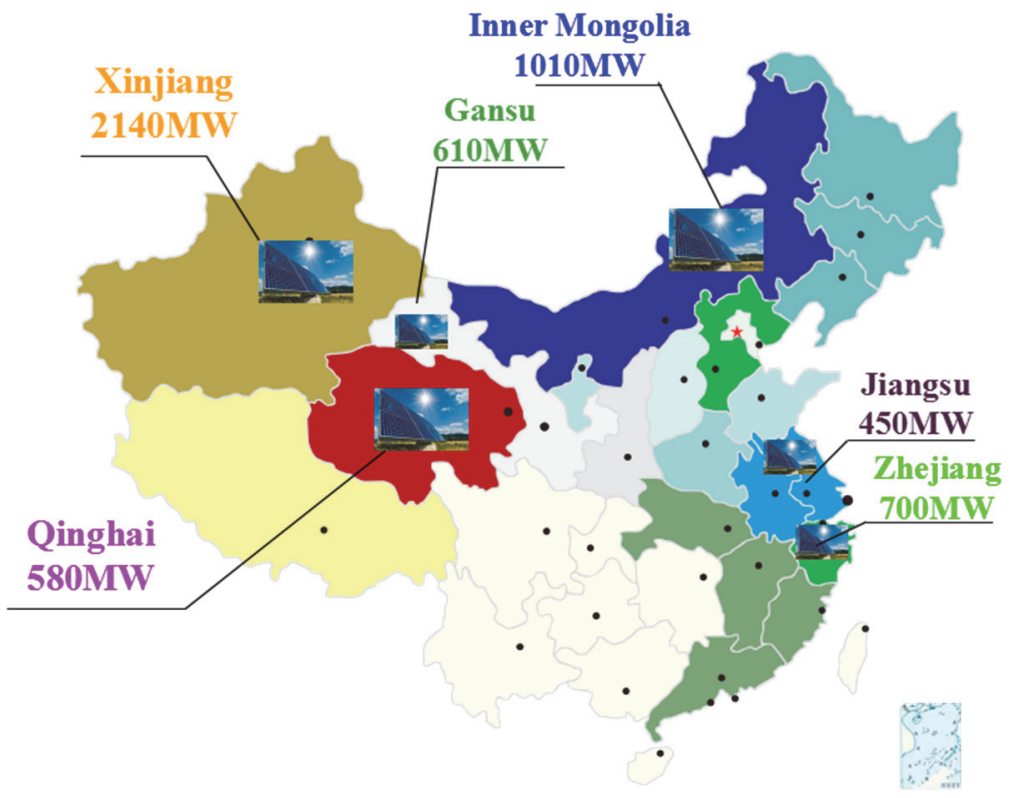

Figure 14. New installed capacity of PV power generation in the first half of 2015

\subsection{Analysis of Weakness Factors}

\subsubsection{CO2 Emissions}

The EDGAR of the European Commission and The Netherlands Environmental Assessment Agency announced the level of CO2 emissions of major countries in the world in 2014 (Macdougall \& Friedlingstein, 2015) (Note 10, 11). Fig. 15 shows the energy-related $\mathrm{CO} 2$ emissions of selected regions. China's energy-related $\mathrm{CO} 2$ emissions are increasing and among the highest worldwide. The energy-related $\mathrm{CO} 2$ emissions of China, the United States, the European Union, India, Russia, and Japan reach more $80 \%$ of the world total. To improve the living environment and promote sustainable economic development, all countries, especially China, should implement energy reforms. Thus, in the 13th Five-Year Plan (2016-2020), China will intensify comprehensive energy reform, drive energy revolution positively, and develop energy through green, safe, and sustainable means (Hossain et al., 2015).

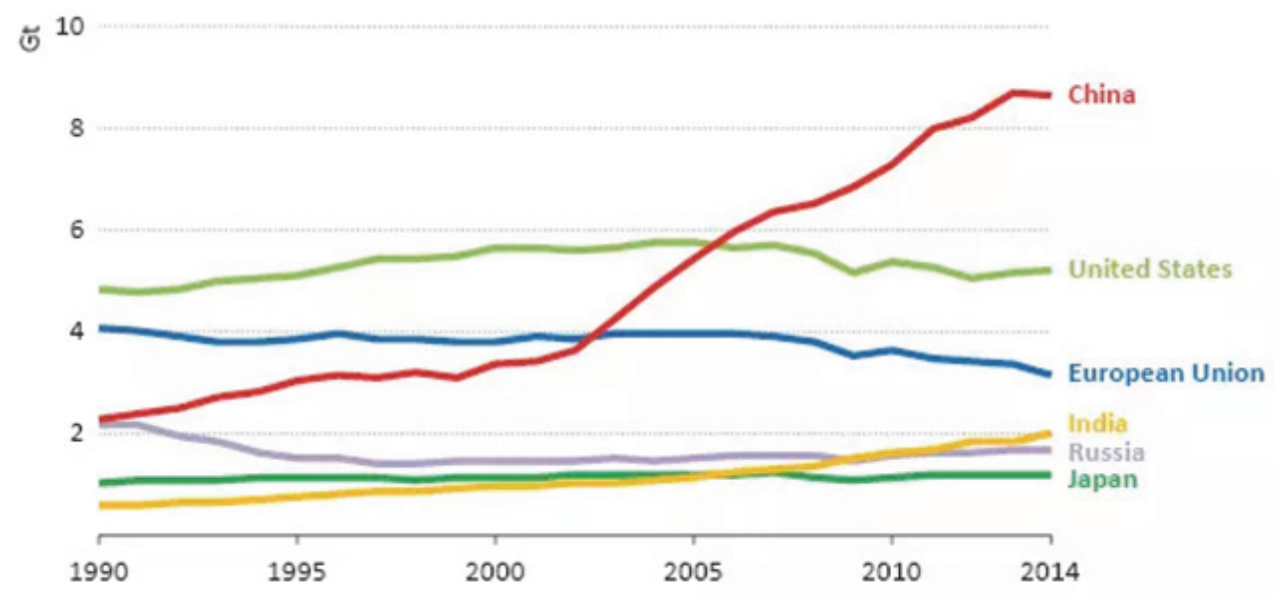

Figure 15. Energy-related $\mathrm{CO} 2$ emissions by selected regions 


\subsubsection{Analysis of Opportunity Factors}

Primary energy consumption structure in China

According to BP Statistical Review of World Energy 2015, China's primary energy consumption of crude oil and raw coal is decreasing annually, whereas the country's consumption of natural gas, hydropower, and renewable energy are rapidly increasing, as shown in Table 10 (Petroleum, 2015) (Note 1).

Table 10. China's primary energy consumption percentage

\begin{tabular}{llllllll}
\hline Time & $\begin{array}{l}\text { Crude } \\
\text { oil }\end{array}$ & $\begin{array}{l}\text { Natural } \\
\text { gas }\end{array}$ & Coal & $\begin{array}{l}\text { Nuclear } \\
\text { energy }\end{array}$ & $\begin{array}{l}\text { Hydraulic } \\
\text { power }\end{array}$ & $\begin{array}{l}\text { Renewable } \\
\text { energy }\end{array}$ & $\begin{array}{l}\text { Total energy consumption / } \\
\text { Gt standard oil }\end{array}$ \\
\hline 2003 & 22.1 & 2.4 & 69.3 & 0.8 & 5.3 & -- & 102.42 \\
2004 & 22.4 & 2.5 & 68.7 & 0.8 & 5.6 & -- & 142.35 \\
2005 & 20.9 & 2.6 & 69.9 & 0.8 & 5.7 & -- & 156.67 \\
2006 & 20.4 & 2.9 & 70.2 & 0.7 & 5.7 & -- & 172.98 \\
2007 & 19.5 & 3.4 & 70.5 & 0.8 & 5.9 & -- & 186.28 \\
2008 & 18.8 & 3.6 & 70.2 & 0.8 & 6.6 & -- & 200.25 \\
2009 & 17.7 & 3,7 & 71.2 & 0.7 & 6.4 & 0.3 & 218.77 \\
2010 & 17.6 & 4.0 & 70.5 & 0.7 & 6.7 & 0.5 & 243.22 \\
2011 & 17.7 & 4.5 & 70.4 & 0.7 & 6.0 & 0.7 & 261.32 \\
2012 & 17.7 & 4.7 & $\mathbf{6 8 . 5}$ & 0.9 & 7.1 & $\mathbf{1 . 2}$ & 273.52 \\
2013 & 17.8 & 5.1 & $\mathbf{6 7 . 5}$ & 0.9 & 7.2 & $\mathbf{1 . 5}$ & 285.24 \\
2014 & 17.5 & 5.6 & $\mathbf{6 6 . 0}$ & 1 & 8.1 & $\mathbf{1 . 8}$ & 297.21 \\
\hline
\end{tabular}

Coal

According to BP Statistical Review of World Energy 2015, China's coal production and consumption rank first in the world (Petroleum, 2015) (Note 1). China's remaining recoverable coal reserve is inferior to that of the United States and Russia, which rank third in the world. However, the country's reserve production ratio of 30 years is lower than that of Russia, the United States, Australia, and India. From 2011 onwards, China's coal imports have exceeded Japan. Thus, China is the world's largest coal importer. Table 11 (In 2014, five largest producer of coal in the world) shows that the difference between consumption and production is very high (Note 10,11).

Table 11. In 2014, five largest producer of coal in the world

\begin{tabular}{cccccccc}
\hline & \multicolumn{2}{c}{ Remaining recoverable reserves } & \multicolumn{2}{c}{ Production } & \multicolumn{3}{c}{ Consumption } \\
Country & $10^{6}$ tons & $\%$ & $\begin{array}{c}\text { Reserve } \\
\text { production ratio }\end{array}$ & $\begin{array}{c}10^{6} \text { tons oil } \\
\text { equivalent }\end{array}$ & $\%$ & $\begin{array}{c}10^{6} \text { tons oil } \\
\text { equivalent }\end{array}$ & $\%$ \\
\hline USA & 237295 & 26.6 & 262 & 507.8 & 12.9 & 543.4 & 11.7 \\
Russia & 157010 & 17.6 & 441 & 170.9 & 4.3 & 85.2 & 2.2 \\
China & $\mathbf{1 1 4 5 0 0}$ & $\mathbf{1 2 . 8}$ & $\mathbf{3 0}$ & $\mathbf{1 8 4 4 . 6}$ & $\mathbf{4 6 . 9}$ & $\mathbf{1 9 6 2 . 4}$ & $\mathbf{5 0 . 6}$ \\
Australia & 76400 & 8.6 & 155 & 280.8 & 7.1 & 43.8 & 1.1 \\
India & 60600 & 6.8 & 94 & 243.5 & 6.2 & 360.2 & 9.3 \\
World & $\mathbf{8 9 1 5 3 1}$ & $\mathbf{1 0 0}$ & $\mathbf{1 1 0}$ & $\mathbf{3 9 3 3 . 5}$ & $\mathbf{1 0 0}$ & $\mathbf{3 8 8 1 . 8}$ & $\mathbf{1 0 0}$ \\
\hline
\end{tabular}

According to China's Statistical Yearbook from 2002 to 2014, Chinese coal production increased to more than 200 million tons per year in 13 years because of market pulling. These figures are shown in Fig. 16. The growth of coal production decreased since 2012. Chinese coal production in 2013 was 3.71 billion tons, which increased to about 60 million tons. In 2014, the production was 3.87 billion tons, which increased to 160 million tons (Macdougall \& Friedlingstein, 2015; Hossain et al., 2015). 


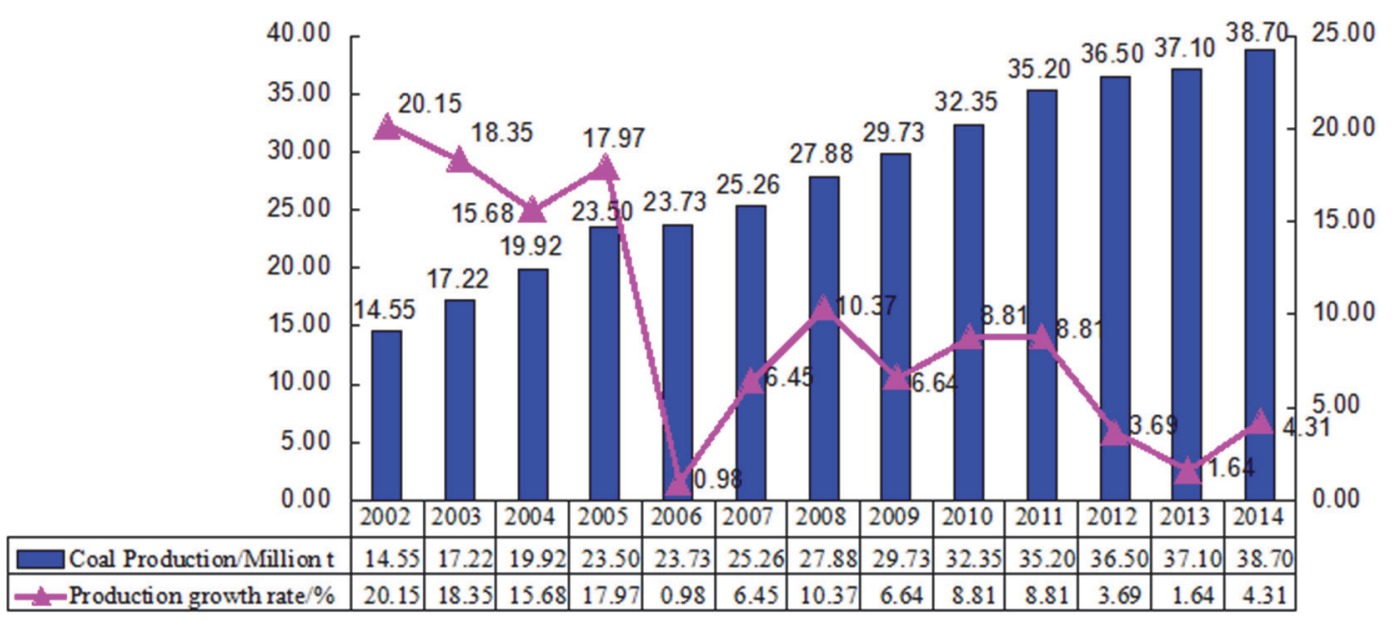

Figure 16. Coal production in China (2002-2014)

According to the National Economy and Society Developed Statistical Bulletin (2002-2014), which was published by the National Statistics Bureau, China's demand for increased to 200 million tons per year from 2001 to 2013, and coal comprised about 70\% of China's primary energy (Liu \& Luan, 2015) (Note 8). In 2014, China's coal consumption became negative for the first time, as shown in Fig. 16. Renewable energy, such as hydropower, wind energy, solar, and biomass energy, developed rapidly in China and occupied an increasingly large share in the energy market. Renewable energy decreased the ratio of coal in energy consumption. The excess capacity and shock of import also decreased the benefit of the coal industry.

As shown in Fig. 17, system theory is used to analyze China's coal industry based on resource exploitation, production, transportation, deep processing, marketing, inventory, and consumption (Liu \& Luan, 2015; Hu \& Zhang, 2015).

Based on the summary analysis of system theory, the imbalance between supply and demand in the Chinese coal market will continue under the new normal. The economy of coal supply exceeds the demand. Thus, control measures should be placed in the whole industry chain, particularly by improving the level of production technology, actively promoting coal deep processing, converting excess coal production capacity, improving inventory digestion backlog, and expanding the coal derivatives market (Hong et al., 2015; Chong et al., 2015).

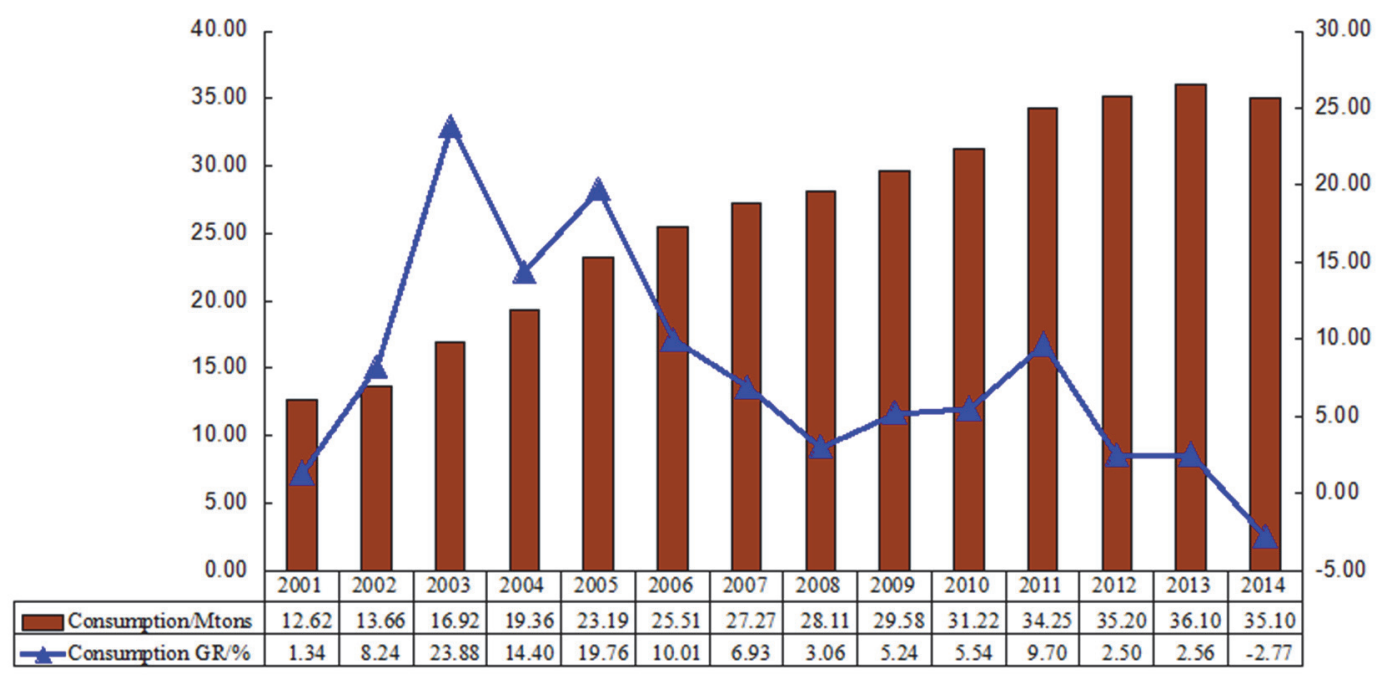

Figure 17. Coal consumption in China (2002-2014) 


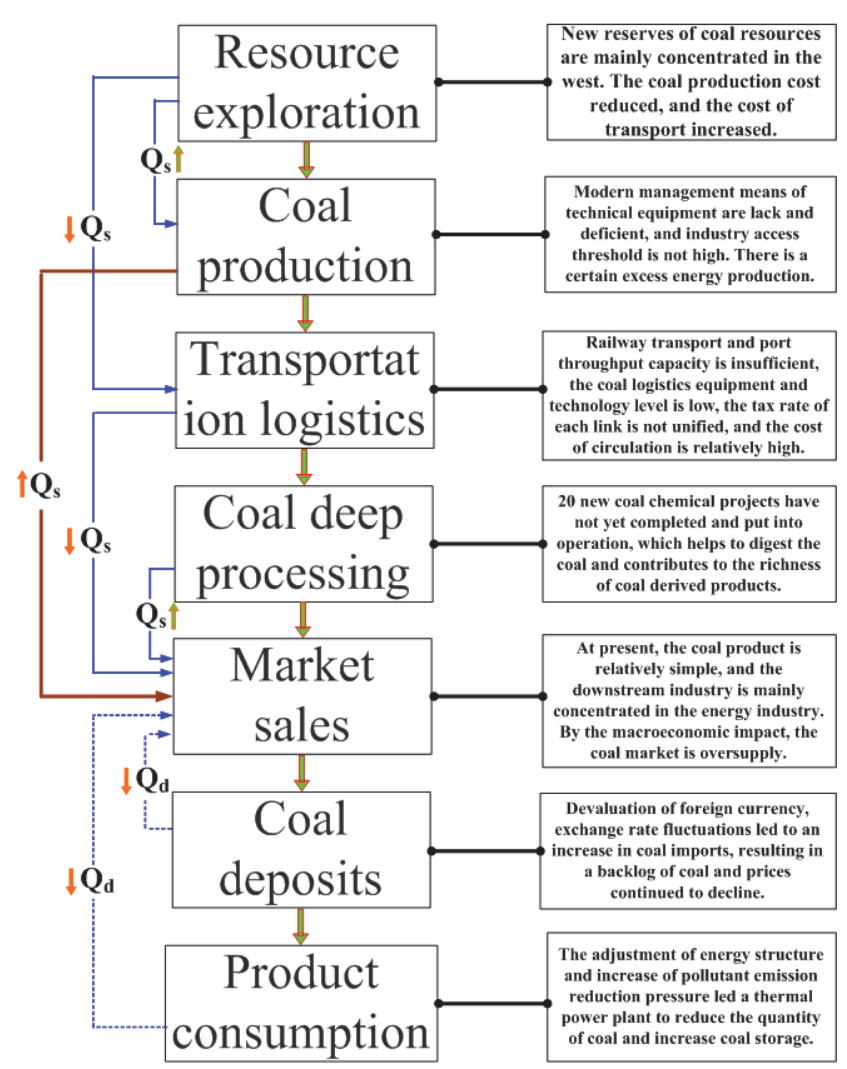

Figure 18. Coal industry chain system analysis (Qs: coal supply, Qd: coal demand)

Middle East crude oil import

China's crude oil imports are mainly obtained from the Middle East, including Saudi Arabia, Iraq, Iran, Oman, Kuwait, Arabia United Arab Emirates, and Qatar. According to BP Statistical Review of World Energy 2015, the volume of China's the Middle East crude oil import increased annually, as shown in Fig. 19. In 2014, this volume accounted for $46 \%$ of China's total crude oil import. This situation is bad for China's energy security; however, China cannot find a better way to solve this problem at present (Petroleum, 2015; Qian \& Xin, 2015).

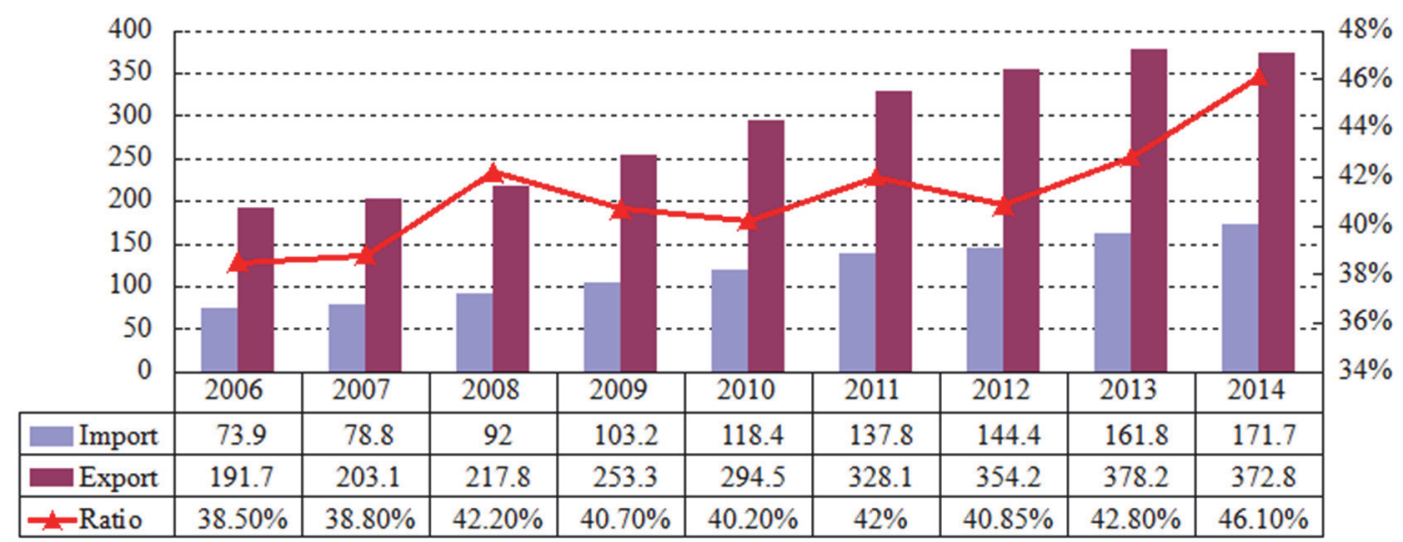

Figure 19. Middle East crude oil import

Natural gas sources

Given China's situation, the development of the natural gas industry in the country must take advantage of domestic and foreign resources. China's natural gas has been obtained from single domestic production and from the supply of foreign multi-channels, that is, through natural gas pipeline transportation and the sea transport of 
liquefied natural gas into China (Li et al., 2015; Wang et al., 2015). However, according to BP Statistical Review of World Energy 2015, China's natural gas sources has decreased year-by-year. This result is shown in Table 12, which provides China's natural gas self-sufficiency rate. This situation is dangerous for China's energy security (Petroleum, 2015; Szoplik, 2015).

Table 12. Natural gas sources in China/108 $\mathrm{m}^{3}$

\begin{tabular}{llllllll}
\hline Time & $\begin{array}{l}\text { Domestic } \\
\text { production }\end{array}$ & Pipe output & $\begin{array}{l}\text { LNG } \\
\text { import }\end{array}$ & ship & Total & Consumption & $\begin{array}{l}\text { Self-sufficiency } \\
\text { rate\% }\end{array}$ \\
\hline 2006 & 586 & -- & 10 & 596 & 561 & 104 \\
2007 & 692 & -- & 39 & 731 & 705 & 98 \\
2008 & 803 & -- & 44.5 & 847.5 & 813 & 99 \\
2009 & 852 & -- & 76 & 928 & 895 & 95 \\
2010 & 968 & 35.5 & 128 & 1131.5 & 1090 & 89 \\
2011 & 1025 & 143 & 166 & 1334 & 1307 & 78 \\
2012 & 1072 & 214 & 200 & 1486 & 1438 & 75 \\
2013 & 1171 & 274 & 245 & 1690 & 1616 & 72 \\
2014 & 1345 & 313 & 271 & 1929 & 1855 & 73 \\
\hline
\end{tabular}

Note. China's natural gas sources (Self-sufficiency rate $=($ Total production/Consumption $) \times 100, \%)$

Domestic natural gas

China's natural gas production continues to maintain an upward trend. Conventional gas data resources from China's total oil field output, shale gas, and coal bed methane are provided by the Ministry of Land and Resources. Domestic natural gas from 2008 to 2014 is shown in the Table 13, which shows that domestic natural gas production increased year-by-year. Natural gas is better than coal and oil; however, the efficiency and environmental protection of coal and oil is worse than that of new energy (Szoplik, 2015; Tang et al., 2015; Leopold, 2016).

Table 13. Domestic natural gas from 2008 to 2014

\begin{tabular}{llllllll}
\hline Time & 2008 & 2009 & 2010 & 2011 & 2012 & 2013 & 2014 \\
\hline $\begin{array}{l}\text { Conventional gas } \& \\
\text { shale gas }\end{array}$ & $\mathbf{7 7 4 . 7}$ & $\mathbf{8 4 0 . 6}$ & $\mathbf{9 8 4}$ & $\mathbf{1 0 0 7 . 6}$ & $\mathbf{1 0 7 4 . 3}$ & $\mathbf{1 1 7 9 . 3}$ & $\mathbf{1 2 7 7}$ \\
PetroChina & 617.5 & 682.5 & 722.5 & 752 & 792.5 & 879.7 & 948.5 \\
Sinopec & 81.2 & 83.3 & 123.6 & 143.9 & 166.6 & 183.9 & 198.4 \\
CNOOC & 76.1 & 74.8 & 101.7 & 111.5 & 112.6 & 111 & 124.1 \\
Extended oil & - & - & 0.1 & 0.2 & 2.6 & 4.7 & 6 \\
Coal bed gas & $\mathbf{5}$ & $\mathbf{1 0 . 1}$ & $\mathbf{1 5}$ & $\mathbf{2 3}$ & $\mathbf{2 5 . 7}$ & $\mathbf{3 0}$ & $\mathbf{3 5 . 4 7}$ \\
Total & $\mathbf{7 7 9 . 7}$ & $\mathbf{8 5 0 . 7}$ & $\mathbf{9 6 3}$ & $\mathbf{1 0 3 0 . 6}$ & $\mathbf{1 1 0 0}$ & $\mathbf{1 2 0 9 . 3}$ & $\mathbf{1 3 1 2 . 4 7}$ \\
\hline
\end{tabular}

\subsubsection{Structure of electric power production}

The statistical data of China's Statistical Yearbook in 2015, which was obtained from the China National Bureau, show that China's power supply mainly comes from thermal power generation, which accounts for $75 \%$ to $80 \%$ of the country's energy supply. As shown in Table 14, coal power is the dominant power source. From 2013 onwards, wind power capacity outweighed that of nuclear power generation (Note 12).

Table 14. Electric power production structure in China's $/ 108 \mathrm{kWh}$

\begin{tabular}{lllllllll}
\hline Time & 2013 & 2012 & 2011 & 2010 & 2009 & 2008 & 2007 & 2006 \\
\hline Available supply & 54204.1 & 49767.7 & 47002.7 & 41936.5 & 37032.7 & 34540.8 & 32712.4 & 28588.4 \\
Output & 54316.4 & 49875.5 & 47130.2 & 42071.6 & 37146.5 & 34668.8 & 32815.5 & 28657.3 \\
Hydropower & 9202.9 & 8721.1 & 6989.5 & 7221.7 & 6156.4 & 5851.9 & 4852.6 & 4357.9 \\
Thermal power & 42470.1 & 38928.1 & 38337 & 33319.3 & 29827.8 & 27900.8 & 27229.3 & 23696 \\
Nuclear power & 1116.1 & 973.9 & 863.5 & 738.8 & 701.3 & 683.9 & 621.3 & 548.4
\end{tabular}




\begin{tabular}{|c|c|c|c|c|c|c|c|c|c|}
\hline Wind power & & 1412 & 959.8 & 703.3 & 446.2 & -- & -- & -- & -- \\
\hline Imported & & 74.4 & 68.7 & 65.6 & 55.5 & 60.1 & 38.4 & 42.5 & 53.9 \\
\hline Exit & & 186.7 & 176.5 & 193.1 & 190.6 & 173.9 & 166.4 & 145.7 & 122.7 \\
\hline $\begin{array}{l}\text { Electric } \\
\text { consumption }\end{array}$ & power & 54203.4 & 49762.6 & 47000.9 & 41934.5 & 37032.2 & 34541.4 & 32711.8 & 28588 \\
\hline
\end{tabular}

\subsubsection{New Energy Development Issues}

This paper explores two new energy development issues (Dent, 2015) (Note 13). Wind power curtailment and PV power curtailment are serious issues. The latest statistics from the National Energy Bureau show that the total wind power curtailment reached $17.5 \mathrm{TWh}$ at a curtailment rate of $15.2 \%$. These figures increased to $10.1 \mathrm{TWh}$ at an increasing rate of $6.8 \%$ in the half of 2015. The total PV power curtailment in China reached $1.8 \mathrm{TWh}$, mainly in Xinjiang and Gansu areas.

Subsidies to new energy companies are increasingly becoming serious. By the end of 2014, the renewable energy fund subsidies to enterprises reached 17,000,000,000 yuan including arrears. In the first half of 2015, the estimated total arrears reached 20,000,000,000 yuan.

If these two problems will not be solved, China will be facing financing problems. Technological progress will lose its power and will affect the industrial development (Chang et al., 2017; Fan et al., 2015; Pei et al., 2015).

According to Qin Haiyan, Secretary General of the China Wind Energy Association, wind power curtailment in the first quarter of 2015 reached half of that in 2012, which witnessed the most serious wind power curtailment in China. The high proportion of wind power curtailment also appeared in local areas. The information construction of photovoltaic power generation in the first half of 2015, which was released by National Energy Bureau, announced the national PV power curtailment data. Data show that the national total PV power generation capacity in the first six months of 2015 is $19 \mathrm{TWh}$; PV power curtailment is $1.8 \mathrm{TWh}$, which mainly occurred in Gansu and accounts for 28\% and that in Xinjiang accounts for 19\% (Note 14). Wind power curtailment from 2010 to 2014 are shown in Fig. 19. Wind power curtailment in main provinces in 2014 is shown in Table 15 (Chang et al., 2017; Fan et al., 2015).

Table 15. Wind power curtailment of main provinces in 2014

\begin{tabular}{|c|c|c|c|c|c|c|c|}
\hline Rank & Province & $\begin{array}{c}\text { CIC/G } \\
\mathbf{W}\end{array}$ & NGC/MW & $\begin{array}{c}\text { CGC/M } \\
\mathbf{W}\end{array}$ & $\begin{array}{c}\text { GE/TW } \\
\mathbf{h}\end{array}$ & $\mathbf{C W P} / \mathbf{W h}$ & $\begin{array}{c}\text { PCWP/ } \\
\%\end{array}$ \\
\hline $\mathbf{1}$ & Jilin & 4.65 & 689.2 & 4256.6 & 9.87 & 5.37 & 25.24 \\
\hline $\mathbf{2}$ & Heilongjiang & 5.53 & 1336.3 & 5109.7 & 15.57 & 5.14 & 24.82 \\
\hline 3 & IM & 22.31 & 2309.8 & 20185.6 & 83.22 & 16.9 & 23.03 \\
\hline $\mathbf{4}$ & Xinjiang & $\mathbf{9 . 6 7}$ & $\mathbf{2 4 8 . 9}$ & $\mathbf{9 0 1 2 . 0}$ & $\mathbf{2 5 . 3 2}$ & $\mathbf{5 . 8 8}$ & $\mathbf{1 8 . 8 5}$ \\
\hline $\mathbf{5}$ & Liaoning & 7.11 & 1091.5 & 6953.8 & 20.02 & 4.24 & 17.48 \\
\hline $\mathbf{6}$ & Hebei & 9.87 & 1729.8 & 9056.6 & 39.22 & 7.89 & 16.75 \\
\hline $\mathbf{7}$ & Gansu & $\mathbf{1 0 . 7 3}$ & $\mathbf{2 5 4 1 . 3}$ & $\mathbf{9 7 6 8 . 7}$ & $\mathbf{2 7}$ & $\mathbf{1 . 7 7}$ & $\mathbf{6 . 1 5}$ \\
\hline $\mathbf{8}$ & Shandong & 8.26 & 1282.8 & 8005.1 & 26.17 & 0.7 & 2.61 \\
\hline $\mathbf{9}$ & Shanxi & 5.86 & 1921.0 & 5673.6 & 17.15 & 0.33 & 1.89 \\
\hline 10 & Ningxia & 6.14 & 2501.3 & 5893.2 & 15.13 & 0 & 0 \\
\hline
\end{tabular}




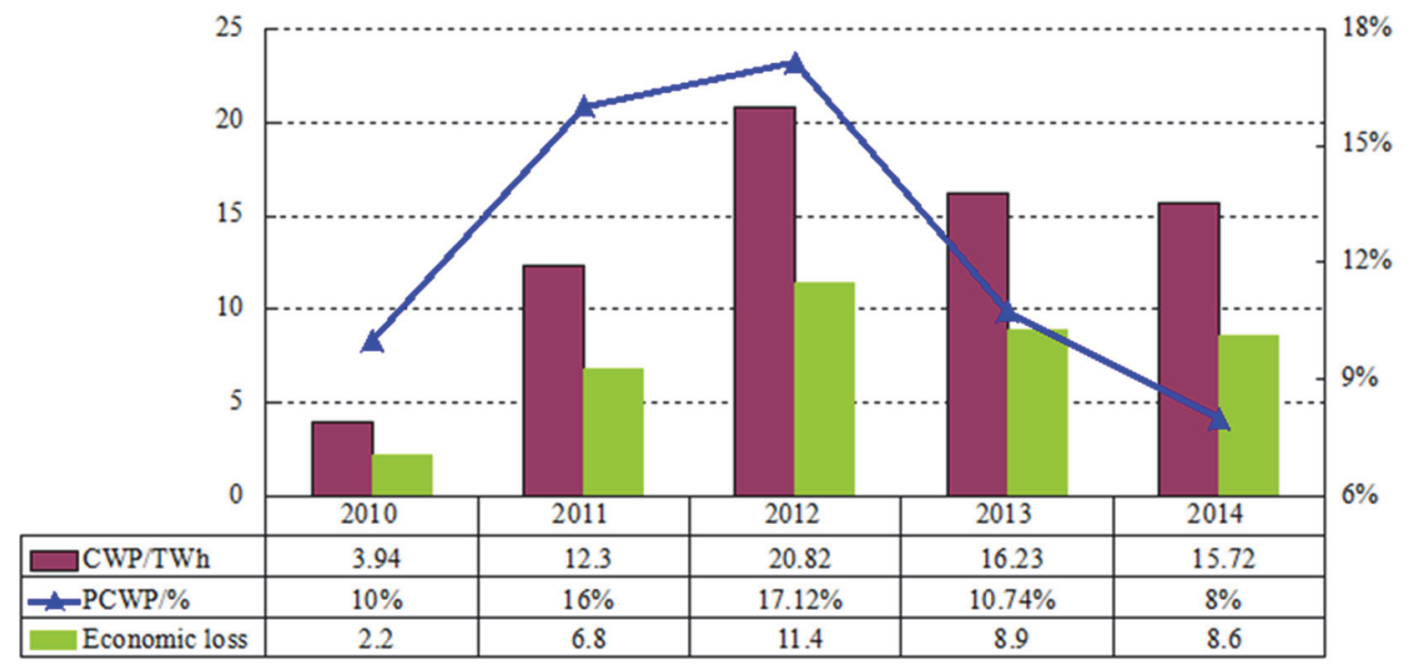

Figure 20. Wind power curtailments from 2010 to 2014

As the country's major new energy province, Gansu's new energy generation capacity during the first half of this year was more than $10 \mathrm{TWh}$. This figure accounts for $16 \%$ of the province's power generation, which is higher than the national average. Prediction of installed wind power grid capacity of more than 13,000,000 kilowatts and installed photoelectric grid capacity of 6,000,000 kilowatts will be presented by the end of this year (Note 14).

However, Meng Kai, the director of Energy Bureau of Gansu Province admitted that: "The rapid development of new energy is subjected to market constraints, absorptive capacity, peaking capacity, and channel transmission capability. The new energy industry in Gansu showed a more serious phenomenon of wind power and PV power curtailment." This year, the wind power curtailment situation in Gansu province become a serious issue. Data for the first half year show that the average utilization hours of wind power in the province is the lowest in the country. This figure further decreased to 185 hours. The rate of wind power curtailment is $30.98 \%$, which is second only to Jilin province. However, thermal power enterprises in this case obtain priority access to the grid, which should belong to renewable energy power through "direct supply"; this misuse of the power to channel resources results in further losses of wind power companies (Note 14).

The factors that exacerbated wind power and PV power curtailment are: 1 . The mismatch between the new energy installed capacity and the grid. 2. The lack of peaking capacity of thermal power units and the lack of system planning, operation, and management of power source (Fan et al., 2015; Li et al., 2015) (Note 15).

Wind power and PV power curtailment increased in half of 2015. This increase is attributed to stronger wind, decreased demand for electricity, and the mismatch between new installed energy capacity and the grid. In addition, the scale of thermal power project construction remained at a high level even when China's economic development slowed down.

Statistics show that the newly approved thermal power projects reached more than $58000 \mathrm{MW}$ in the first five months of this year. These thermal power projects all over the country have reached $0.19 \mathrm{TW}$, which is a shocking figure. The contradiction between thermal power and new energy will become more acute in the next few years (Note 15, 16).

\subsection{Analysis of Opportunity Factors}

\subsubsection{Urbanization}

Urbanization refers to the process of urban agglomeration of population, urban scale expansion, and a series of economic and social changes. Thus, urbanization is the change of spatial, economic, and social structure. Urban energy consumption accounts for about $80 \%$ of total energy consumption, especially natural gas consumption (Note 17, 18).

Table 16 shows the urbanization in East Asia, North America and Western Europe according to 2014 statistics of the United Nations. The highest level of urbanization was observed in North America at $81.5 \%$. East Asia's urbanization is low; China's urbanization percentage is only $54.4 \%$, which is lower than the average level of East 
Asia and slightly higher than the global average of water (Tessler et al., 2015; Akal, 2015). If the level of urbanization in China is low, energy cannot be fully utilized, which is unfavorable to the development of the energy industry.

Table 16. Urbanization Ratio in some countries

\begin{tabular}{lllll}
\hline Country & Urban & Rural & Total & Urbanization Ratio \\
\hline East Asia & $\mathbf{9 6 0 2 3 5}$ & $\mathbf{6 6 9 1 1 8}$ & $\mathbf{1 6 2 9} \mathbf{4 2 1}$ & $\mathbf{5 8 . 9 \%}$ \\
China & $\mathbf{7 5 8 3 6 0}$ & $\mathbf{6 3 5 4 2 4}$ & $\mathbf{1 3 9 3 7 8 4}$ & $\mathbf{5 4 . 4 \%}$ \\
Japan & 118136 & 8864 & 127000 & $93.0 \%$ \\
Korea & 40788 & 8734 & 49512 & $82.4 \%$ \\
North America & $\mathbf{2 9 1 ~ 8 6 0}$ & $\mathbf{6 6 3 7 6}$ & $\mathbf{3 5 8 2 3 6}$ & $\mathbf{8 1 . 5 \%}$ \\
U.S.A & 262734 & 59849 & 322584 & $81.4 \%$ \\
Canada & 29006 & 6519 & 35525 & $81.5 \%$ \\
Western Europe & $\mathbf{1 5 1 4 9 9}$ & $\mathbf{4 1 ~ 0 3 8}$ & $\mathbf{1 9 2 5 3 7}$ & $\mathbf{7 8 . 7 \%}$ \\
France & 51253 & 13388 & 64641 & $79.3 \%$ \\
Germany & 62067 & 20585 & 82652 & $75.1 \%$ \\
Holland & 15107 & 1695 & 16802 & $89.9 \%$ \\
World & $\mathbf{3 ~ 8 8 0 ~ 1 2 8}$ & $\mathbf{3 3 6 3 6 5 6}$ & $\mathbf{7 2 4 3 ~ 7 8 4}$ & $\mathbf{5 3 . 6 \%}$ \\
\hline
\end{tabular}

\subsubsection{GDP}

Each year, four statistical agencies, namely, the IMF, the WB, the UN, and the United States Central Intelligence Agency release an annual report of the world's GDP evaluated with international exchange rate and purchasing power (Note 19, 20, 21).

Due to space constraints, Table 17 only provides the 2014 data from the IMF and WB (Warner, 2015). China's GDP already exceeded Germany. In 2010, China's GDP surpassed Japan; in 2014, China's GDP was twice that of Japan's (Holz, 2013). At present, China's GDP only ranks second in the world, next to the United States. Goldman Sachs estimates that China's GDP will exceed that of the United States in 2025-2030 (Lemoine et al., 2015).

Table 17. GDP top 10 countries in 2014

\begin{tabular}{llllll}
\hline IMF 2014 & & & \multicolumn{3}{l}{ World Bank 2014 } \\
\hline Ranking & Country & GDP/Million dollars & Ranking & Country & GDP/Million dollars \\
1 & USA & 17418925 & 1 & USA & 17419000 \\
$\mathbf{2}$ & China & $\mathbf{1 0 3 8 0 3 8 0}$ & $\mathbf{2}$ & China & $\mathbf{1 0 3 6 0 1 0 5}$ \\
3 & Japan & 4616335 & 3 & Japan & 4601461 \\
4 & Germany & 3859547 & 4 & Germany & 3852556 \\
5 & UK & 2945146 & 5 & UK & 2941886 \\
6 & France & 2846889 & 6 & France & 2829192 \\
7 & Brazil & 2353025 & 7 & Brazil & 2346118 \\
8 & Italy & 2147952 & 8 & Italy & 2144338 \\
9 & India & 2049501 & 9 & India & 2066902 \\
10 & Russia & 1857461 & 10 & Russia & 1860598 \\
UN & & $\mathbf{1 8 4 9 5 3 4 9}$ & UN & & $\mathbf{1 8 4 6 0 6 4 6}$ \\
World & & $\mathbf{7 7 3 0 1 9 5 8}$ & World & & $\mathbf{7 7 ~ 8 6 8 ~ 7 6 8}$ \\
\hline
\end{tabular}

The National Economic and Social Development Statistics Bulletin (2014), which was issued by the China Bureau of Statistics, provides China's energy consumption and GDP conditions. These data are shown in Fig. 21. Since 2012, China's GDP growth remained at around 7.5\%. Thus, China's economic growth is going into the new normal. Under the new normal economic condition, transportation production, sales, import, and export of China's energy industry are changing (Holz, 2013). China's energy industry market is not booming, but the economy will bring new changes and new opportunities to China's energy industry. The elasticity coefficient of energy consumption decreases annually, which shows the improvement of energy use efficiency and the constant improvement of the energy structure (Lemoine et al., 2015; Lin et al., 2015). 


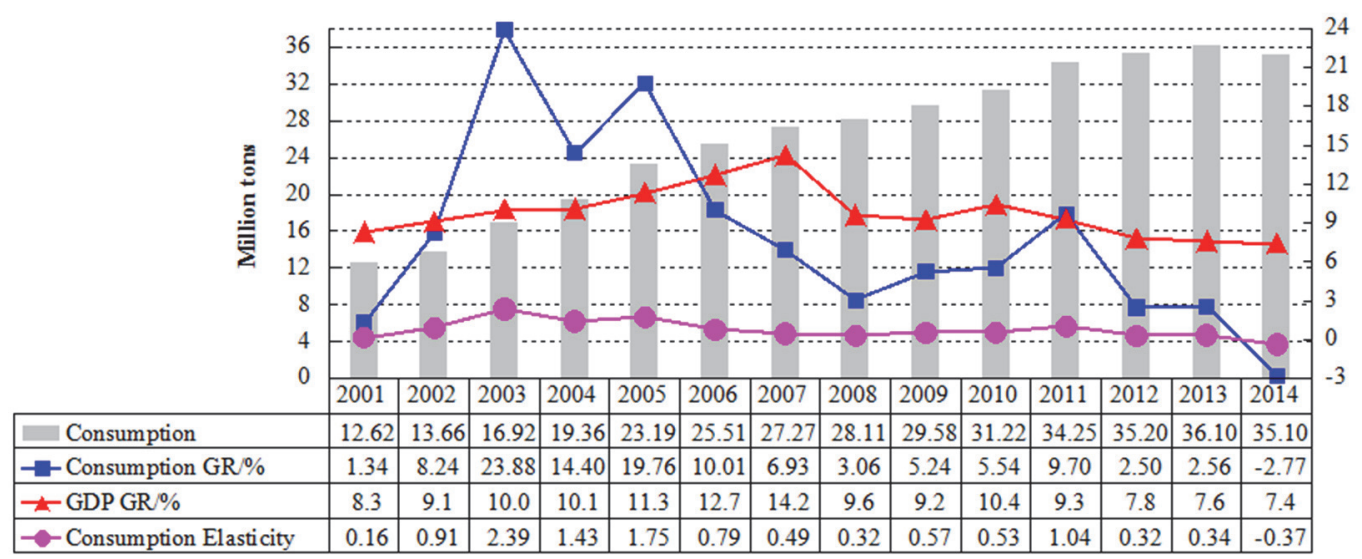

Figure 21. Conditions of China's energy consumption and GDP

\subsubsection{International Trade}

According to the World Trade Organization (WTO) and the CIA World Factbook of the Central Intelligence Agency, China's international trade has a good ranking worldwide, wherein energy trade accounts for a large proportion, as shown in Table 18 (Note 22).

Table 18. International trade top 10 countries in 2014

\begin{tabular}{lllll}
\hline Ranking & Country & GDP/10 Million dollars & Time & \%GDP(International exchange rate) \\
\hline $\mathbf{1}$ & China & $\mathbf{4 ~ 2 0 1}$ & $\mathbf{2 0 1 4}$ & $\mathbf{4 0 . 5}$ \\
2 & USA & 3944 & 2014 & 22.6 \\
3 & Germany & 2866 & 2014 & 74.3 \\
4 & Japan & 1522.4 & 2014 & 33 \\
5 & France & 1212.3 & 2014 & 42.6 \\
6 & UK & 1189.4 & 2014 & 40.4 \\
7 & Korea & 1171 & 2014 & 82.6 \\
8 & Hongkong & 1088 & 2014 & 375.8 \\
9 & Holland & 1042 & 2014 & 120.2 \\
10 & Italy & 949 & 2014 & 44.2 \\
UN & & $\mathbf{4 4 8 5}$ & $\mathbf{2 0 1 3}$ & $\mathbf{2 4 . 2}$ \\
World & & $\mathbf{3 7 ~ 7 0 6}$ & $\mathbf{2 0 1 3}$ & $\mathbf{5 0 . 5}$ \\
\hline
\end{tabular}

For example, China's manufacturing industry for new energy wind power generation occupies a certain proportion worldwide. According to the statistics provided by the consulting firm Navigating in 2014, three Chinese wind turbine manufacturers are among the top 10 global manufacturers in terms of global sales. These companies are Goldwind, United Power, and Mingyang Wind Power, which account for $20.6 \%$ share of the total global market. The top 10 newly installed wind turbine OEMs in 2014 and their market share changes are shown in Figs. 22 and 23 (Chang et al., 2017; Fan et al., 2015). China's wind power equipment manufacturing industry overcome its dependence on imports and foreign wind power equipment. The market share of domestic wind turbines is now more than $90 \%$. Therefore, China has become a veritable wind power equipment manufacturing country (Lin et al., 2015; Jin et al., 2014).

Given the steady growth of China's international trade, the country's energy industry enjoys a healthy and sustainable development. 


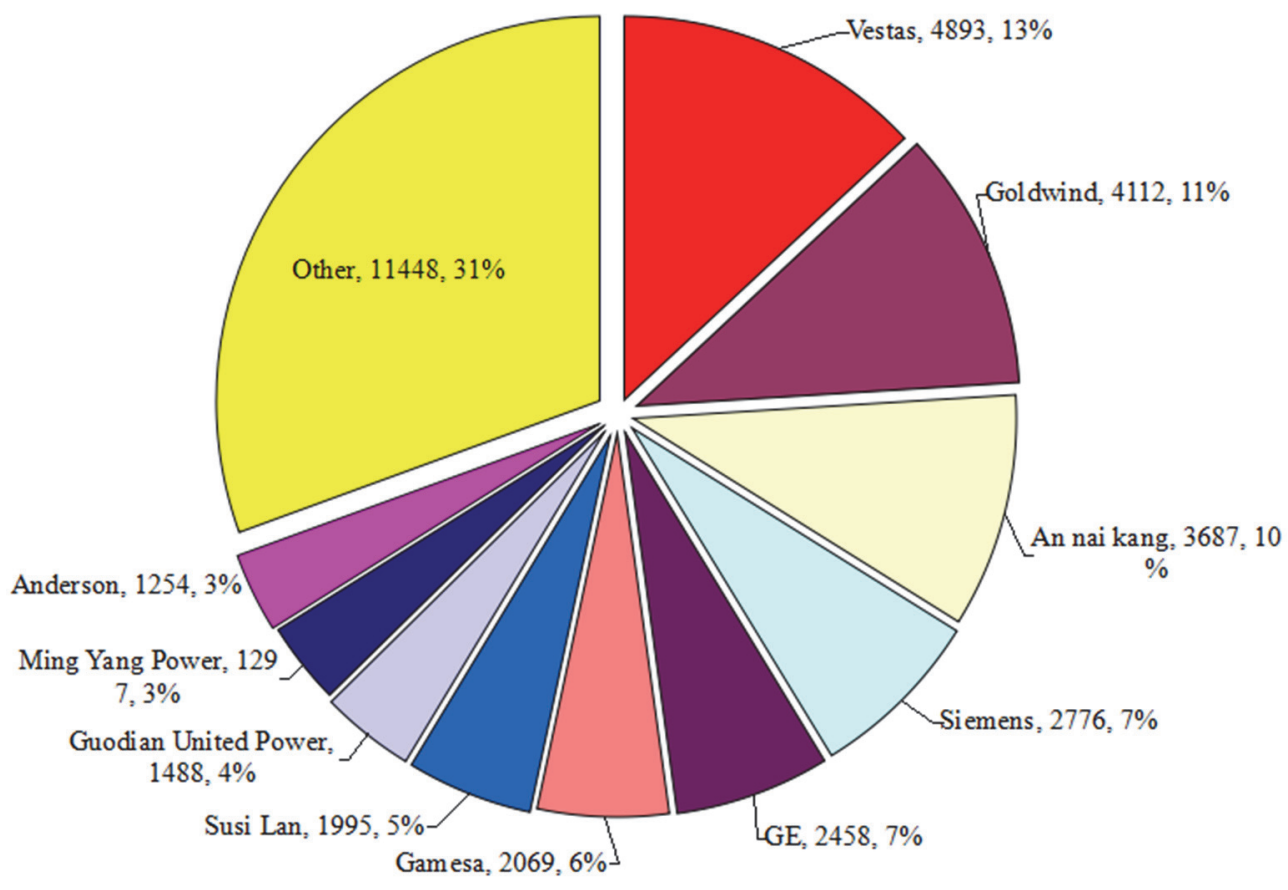

Figure 22. Top ten of the global new installed wind turbine OEMs in 2014

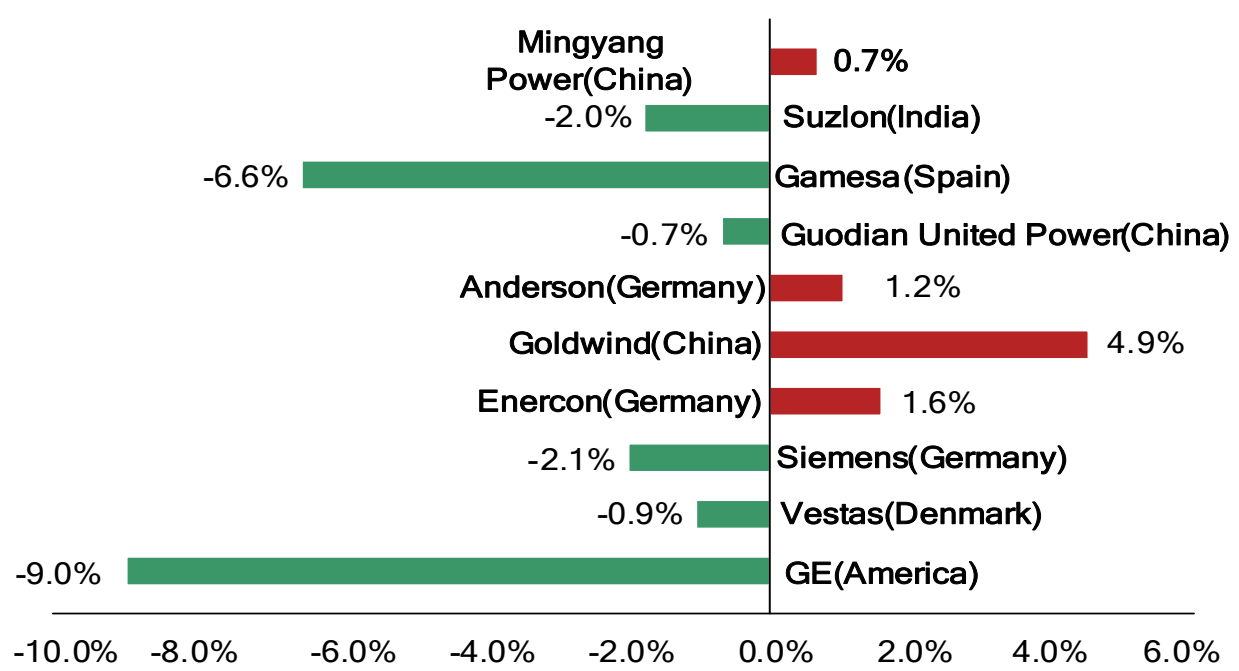

Figure 23. Top ten of the global new installed wind turbine OEMs market share changes in 2014

\subsubsection{Energy Flow}

China's primary energy circulation is mainly centered on the transportation system and the oil and gas pipeline, including main transportation systems, namely, waterway, highway, and railway (Jiang et al., 2015; Li \& Lin, 2015).

Waterway transportation

Waterway length is the length of a navigable river, canal, and inland waterways. Waterways are important for the transportation of energy resource. According to the CIA World Factbook, China's shipping routes ranks first worldwide, which stretches to $110000 \mathrm{~km}$. As shown in Table 19, China's waterway data barely change with time (Note 23). 
Table 19. Waterway length in main countries

\begin{tabular}{llll}
\hline Ranking & Country & Length $/ \mathrm{km}$ & Report Time \\
\hline $\mathbf{1}$ & China & $\mathbf{1 1 0 0 0 0}$ & $\mathbf{2 0 1 1}$ \\
2 & Russia & 102000 & 2009 \\
3 & Brazil & 50000 & 2012 \\
4 & Vietnam & 47130 & 2011 \\
5 & USA & 41009 & 2012 \\
6 & Columbia & 24725 & 2012 \\
7 & Indonesia & 21579 & 2011 \\
8 & Congo & 15000 & 2011 \\
9 & India & 14500 & 2012 \\
10 & Burma & 12800 & 2011 \\
\hline
\end{tabular}

Construction of LNG (liquefied natural gas) transport ship

LNG is a natural gas that was liquefied under certain temperature and pressure. LNG is an economical way to store and transport natural gas, which is suitable for long-distance transportation.

China's first LNG transport ship, Dapeng Hao, was built in 2008. As shown in Fig. 24, Dapeng Hao, which is the world's largest thin film type LNG ship, measures 292 meters in length, 43.35 meters wide, 26.25 meters deep, and has a loading capacity of 147000 cubic meters (Energy. (2015).

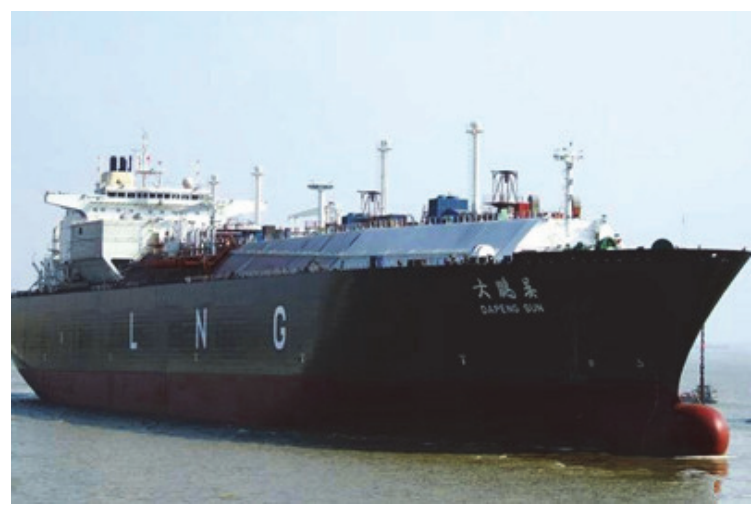

Figure 24. "DAPENG HAO” LNG transport ship built in 2008

On August 5, 2015, China's first 30000 cubic meters LNG ship, Ocean Petroleum 301, which was anchored in Zhuhai, was officially handed over and put into operation by Jiangnan Shipyard Group for the CNOOC. Ocean Petroleum 301 is 184.7 meters in long and 28.1 meters wide, with a full load displacement of about 27750 tons; this ship was built in warehouses of four independent C-type liquid cargo tank, which loads 30000 cubic meters of LNG (Note 24, 25).

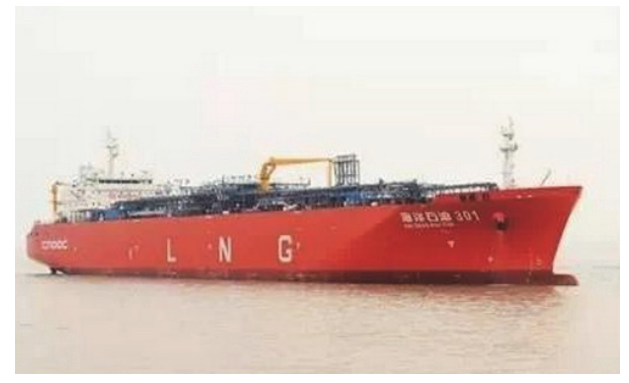

Figure 25. China's first 30000 cubic meters of LNG ship "ocean petroleum 301" in 2015

Energy efficiency and low carbon emission is the development trend of the global shipping industry. Sulfur oxides and other emissions is increasingly being controlled. With the use of LNG as ship fuel, several LNG ships will sail the high seas in the next 5 to 10 years. At present, Europe, the United States, Japan, South Korea, and 
China are actively developing LNG as ship fuel. LNG ship is a special ship with a temperature of $-163{ }^{\circ} \mathrm{C}$; thus, LNG ship is a kind of "super frozen car at sea" (Goel et al., 2015).

The alternative role of LNG in the traditional energy market is increasingly becoming evident. China is the world's marine fuel market. China's Ministry of Transportation studies the framework of green transportation system to promote the sustainable development of transportation. Realizing green shipping is one of the goals of China's green traffic system. To realize green shipping, the alternative fuels in China's shipping industry should include liquefied power ship, alcohol/ether power ship, and fuel cell power ship; LNG power ship develops fastest among these alternative fuels (Abrahams et al., 2015) (Note 26).

According to the Association of the National Shipbuilding Industry in China in May 2015, LNG and its transport vessels originated in Europe and the United States. The production of small LNG transport ships started in the 1970s, and then developed into the production of standard LNG transport ship. The production was later transferred to East Asian countries. The construction of LNG transport ships picked up speed in 2012 with 361 newly constructed LNG ships; this number increased to 415 in 2015 , which is equivalent to an increase of $15 \%$ (Note 27). China demonstrated a rapid development in the LNG shipbuilding industry. As shown in Table 20, only 7 ships are currently in service in China, but 14 ships are still being built; thus, China ranks third in the world, next to South Korea, which has 64 and Japan, which has 15.

The delivery service of the first three LNG carrier construction companies are located in South Korea. The companies that handle delivery services are Samsung, Daewoo, and Hyundai, which are followed by three Japanese companies, namely, Mitsubishi Nagasaki, Kawasaki Sakaide, and Mitsui, Chiba. LNG carrier construction is a rising industry in China, which ranks ninth; China's Hudong Zhonghua ranks third, next to Daewoo and Samsung, as shown in Table 21 (Abrahams et al., 2015) (Note 27).

According to the Energy Development Strategy Plan 2014-2020 of the State Council, the proportion of natural gas in China's total energy consumption will reach $10 \%$ by 2020 , compared with the current $5 \%$ substantial increase. The development of China's own LNG fleet can ensure a stable supply of LNG to grasp the initiative, in case the original LNG supply is insufficient; thus, China can quickly deploy its own LNG ship to carry out transport and avoid gas shortage and other unfortunate events (Note 28).

Table 20. Top 12 countries LNG shipbuilding industry in the world

\begin{tabular}{llll}
\hline Ranking & Country & In service & Building \\
\hline 1 & Korea & 259 & 64 \\
2 & Japan & 100 & 15 \\
$\mathbf{3}$ & China & $\mathbf{7}$ & $\mathbf{1 4}$ \\
4 & France & 22 & - \\
5 & USA & 6 & - \\
6 & Spain & 4 & - \\
7 & Finland & 4 & - \\
8 & Norway & 3 & - \\
9 & Germany & 2 & - \\
10 & Italy & 2 & - \\
11 & Sweden & 2 & - \\
12 & Belgium & 1 & - \\
Total & & $\mathbf{4 1 5}$ & $\mathbf{9 3}$ \\
\hline
\end{tabular}

Table 21. Top 10 companies LNG shipbuilding industry in the world

\begin{tabular}{lllll}
\hline Ranking & Country & Company & In service & Building \\
\hline 1 & Korea & Samsung & 96 & 17 \\
2 & Korea & Daewoo & 93 & 28 \\
$\mathbf{3}$ & Korea & Hyundai & 51 & 11 \\
4 & Japan & MHI Nagasaki & 44 & 9 \\
5 & Japan & Kawasaki Sakaide & 29 & 6 \\
6 & Japan & Mitsui China & 16 & -- \\
7 & France & Atlantique & 13 & -- \\
8 & Korea & Hyundai Samho & 8 & 7
\end{tabular}




\begin{tabular}{lllll}
$\mathbf{9}$ & China & Hudong Zhonghua & $\mathbf{7}$ & $\mathbf{1 3}$ \\
10 & Korea & Hanjin H.I. & 6 & -- \\
Total & & $\mathbf{3 6 3}$ & $\mathbf{9 1}$ \\
\hline
\end{tabular}

\section{Central Asia-China gas pipeline}

The Central Asia-China gas pipeline, which is also called the Turkmenistan-China gas pipeline, is united by PetroChina, Turkmengaz, KazMunayGas, and Uzbekneftegaz (Paltsev \& Zhang, 2015) (Note 29). The Central Asia-China gas pipeline includes four lines, namely, A, B, C, and D, as shown in Fig. 25. The starting point is in Turkmenistan. The gas pipeline then arrives in the China Horgos border after Uzbekistan and Kazakhstan or in the China Wuqia border after Uzbekistan, Tajikistan, and Kyrgyzstan. By 2016, the highest annual natural gas output of $85 \mathrm{Gm} 3$ will be fled into the silk road, as shown in Table 22. From Turkmenistan to Shanghai, the line is 6000 kilometers long. This is the world's longest pipeline.

Table 22. Central Asia-China gas pipeline

\begin{tabular}{ccccccc}
\hline Pipeline & Start: Turkmenistan & End: China & \multicolumn{2}{c}{ Annual gas output } & Length/km & Completed time \\
\hline A & \multirow{2}{*}{ Bagg Delle Gas } & Horgos & \multirow{2}{*}{300} & \multirow{2}{*}{550} & 1833 & 2009.12 \\
B & Dayimu Gas & Horgos & 250 & & 1833 & 2010.10 \\
C & Fuxing Gas & Wuqia & \multicolumn{2}{c}{300} & 1830 & 2014.05 \\
D & \multicolumn{7}{c}{} & & & & \\
\hline
\end{tabular}

Natural gas imported from Central Asia through the pipeline reaches China's natural gas transmission projects from West to East, as shown in Fig. 26. This pipeline now covers 25 provinces, municipalities, autonomous regions, and the Hong Kong Special Administrative Region. This pipeline benefits more than 500 million people. According to China Petroleum statistics, in November 13, 2014, the Central Asia-China gas pipeline operated safely for 1796 days and delivered a total gas output of $100 \mathrm{Gm} 3$. According to estimates, $100 \mathrm{Gm} 3$ of natural gas is equivalent to 133 million tons of coal, which can reduce 142 million tons $\mathrm{CO} 2$ and 2.2 million tons $\mathrm{SO} 2$ emissions (Zhang et al., 2015; Javaid \& Rashid, 2015) (Note 30).

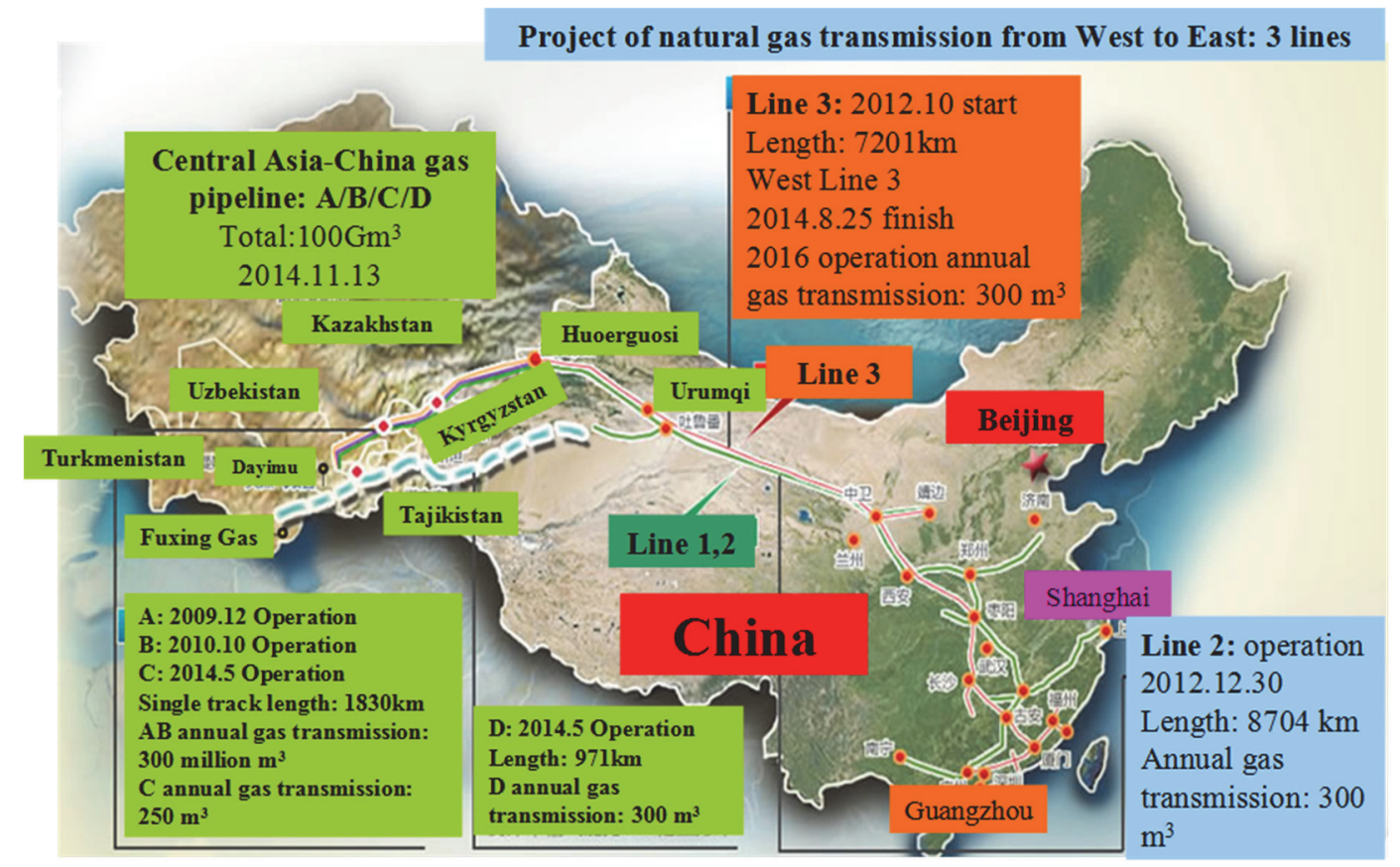

Figure 26. Central Asia-China gas pipeline and project of natural gas transmission from West to East

Natural gas vehicle

Natural gas vehicle is the power provided by using natural gas as fuel. The methane content of natural gas is more than $90 \%$. Thus, natural gas is a good car engine fuel. Natural gas vehicles have been promoted and 
applied worldwide, including various provinces and cities in China. Natural gas vehicles are clean fuel vehicles. Natural gas emissions are lower than those from gasoline-fueled vehicles. The tail gas of these vehicles does not contain sulfur and lead. Carbon monoxide is also reduced by $80 \%$ and hydrocarbons are reduced by $60 \%$. Thus, many countries have developed air vehicles as an important means of reducing air pollution (Sanchespereira et al., 2015).

According to the February 2015 statistics of the Natural Gas Car Magazine, the most natural gas vehicles are in Iran, followed by China ranks. These data are shown in Table 23.

Table 23. Natural gas vehicle in main countries in 2014

\begin{tabular}{|c|c|c|c|c|c|}
\hline Ranking & Country & $\begin{array}{l}\text { Natural } \\
\text { vehicle }\end{array}$ & $\begin{array}{l}\text { Monthly sales of } \\
\text { natural gas } / \mathrm{M} \mathrm{Nm}^{3}\end{array}$ & $\begin{array}{l}\text { Gas filling } \\
\text { station }\end{array}$ & Building \\
\hline 1 & Iran & 4068632 & 630 & 2268 & 512 \\
\hline 2 & China & 3994350 & 416 & 6502 & 2913 \\
\hline 3 & Pakistan & 3700000 & 246 & 2997 & 175 \\
\hline 4 & Argentina & 2487349 & 240 & 1939 & 120 \\
\hline 5 & India & 1800000 & 163 & 936 & 160 \\
\hline 6 & Brazil & 1781102 & 144 & 1805 & 20 \\
\hline 7 & Italy & 885300 & 75 & 1060 & 86 \\
\hline 8 & Columbia & 500000 & 45 & 800 & 72 \\
\hline 9 & Uzbekistan & 450000 & 40 & 213 & 50 \\
\hline 10 & Thailand & 432454 & 184 & 497 & 30 \\
\hline Total & & 22404405 & 2183 & 26677 & 4138 \\
\hline
\end{tabular}

Length of oil and gas pipeline

According to the 2013 CIA World Factbook (Fan et al., 2015), the United States oil and gas pipeline is the most, which accounts for $62.5 \%$ of the world. China's oil and gas pipeline ranks fourth in the world, and accounts for only $2.5 \%$ of the world's total, as shown in Table 24 .

According to China Statistical Yearbook (Note 12), which is published by the China National Bureau of Statistics, the length of China's pipeline in 2014 is 106300 kilometers. The growth of China's oil and gas pipeline is shown in Fig. 27.

Table 24. Length of oil and gas pipeline in main countries

\begin{tabular}{|c|c|c|c|c|c|c|c|}
\hline Country & Natural gas & $\begin{array}{l}\text { Natural gas } \\
\text { condensate }\end{array}$ & LPG & Crude oil & Refined oil & $\begin{array}{l}\text { Oil gas } \\
\text { water }\end{array}$ & Total \\
\hline USA & 1984321 & - & & & 240711 & & 2225032 \\
\hline Russia & 163872 & 122 & 1378 & 80820 & 13658 & 63 & 259913 \\
\hline Canada & 100000 & & & & & & 100000 \\
\hline China & 48502 & 9 & & 23072 & 15298 & 31 & 86912 \\
\hline World & 2863207 & 12011 & 16008 & 298484 & 365686 & 3790 & 3559186 \\
\hline
\end{tabular}

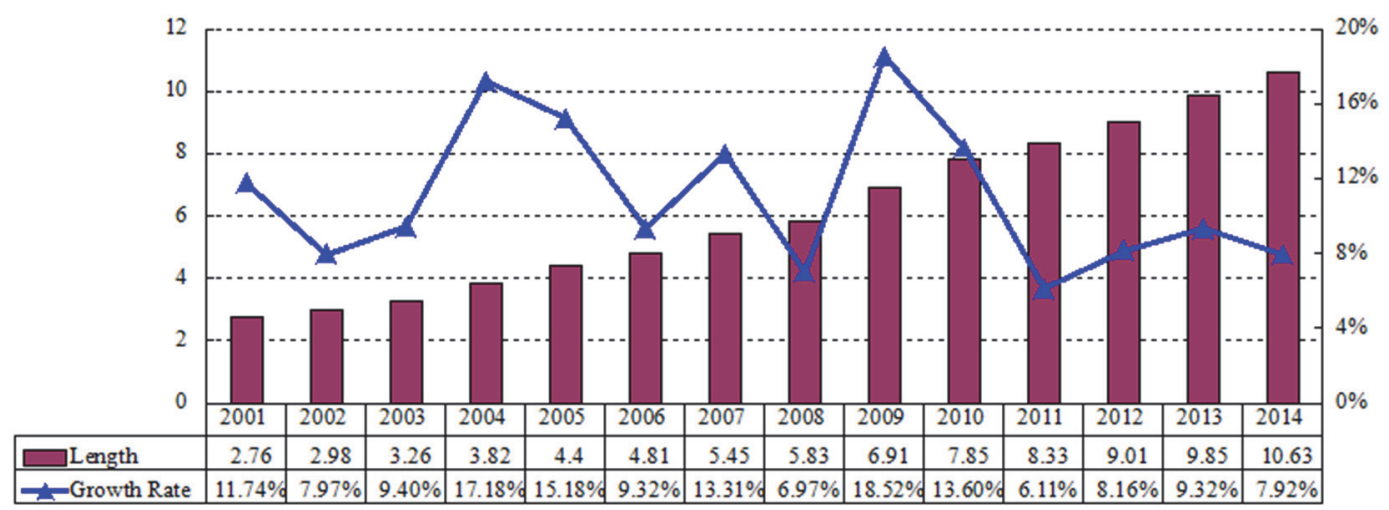

Figure 27. Pipeline length in China from 2001 to 2014 


\subsubsection{UHV Power Grid in China}

The State Grid has introduced the strategic target for developing smart grid in accordance with the characteristics of energy resource and economic situation in China (Ming et al., 2015). In the 12th Five-Year Plan, the State Grid will focus on the construction of main power network that connects wind power bases, hydropower bases, nuclear power bases, photovoltaic power bases, and main load centers. This construction optimizes power structure and power plant layouts. Thus, this approach optimizes resource allocation on a larger scale, establishes an adjustable electricity trading platform, reduces the waste of hydropower and wind power, and reduces the consumption of fossil energy power. After three stages of innovative development, the State Grid announced that a strong smart grid that consumes extra-high voltage synchronous power network will be constructed in 2020 . The smart grid can optimize resource allocation on a larger scale with higher efficiency, which is more secure, more reliable, and has more interactivity (Ding et al., 2015). The smart grid has important significance on recovering cost and encouraging new energy investment to realize clean power transmission. The smart grid construction plan of China during the 12th Five-Year Plan is shown in Fig. 28 (Ming et al., 2013).

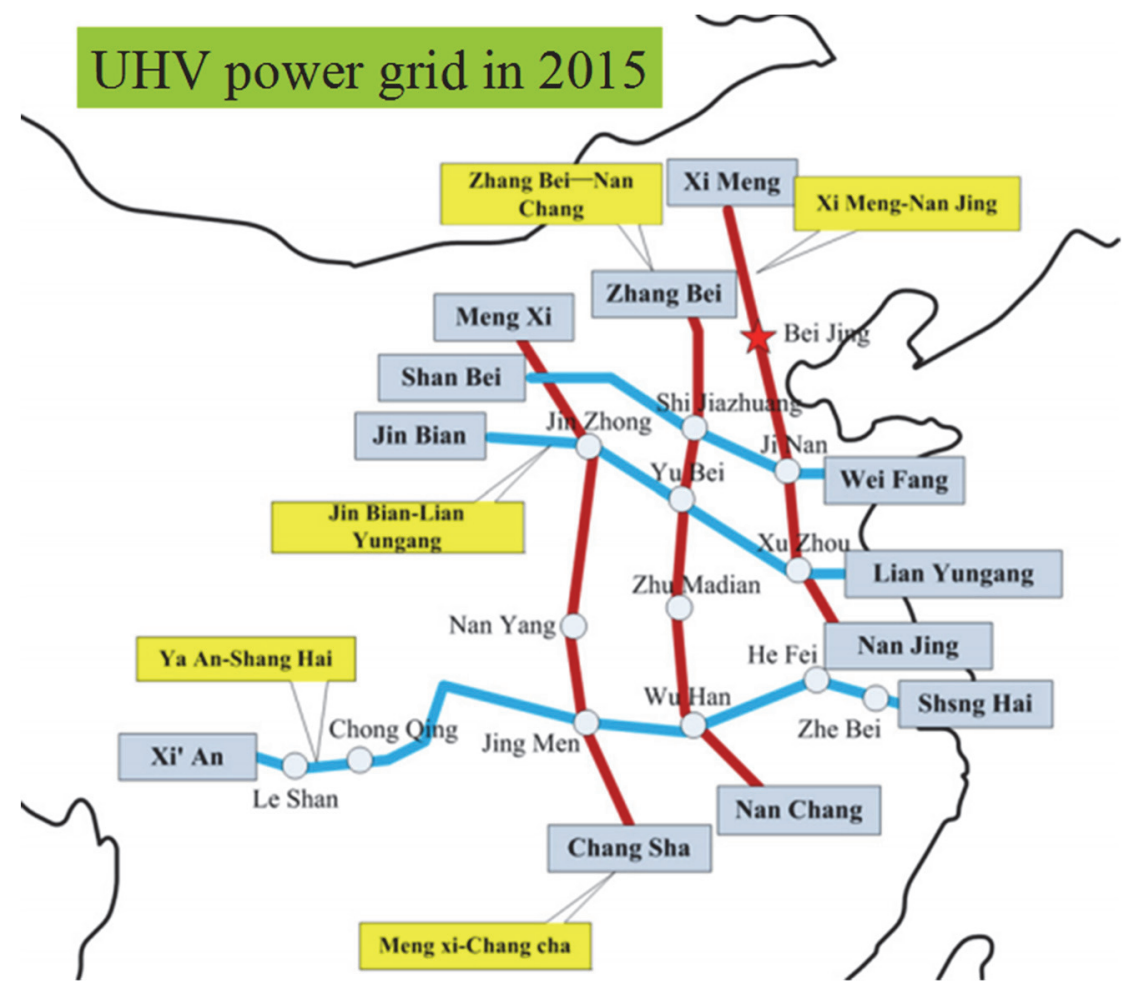

Figure 28. UHV power grid in 2015 (Ming et al., 2013)

\subsubsection{Energy Policy}

One Belt and One Road (OBAOR): The strategic ideas of the new Silk Road Economic Belt and the 21st Century Maritime Silk Road are proposed by President Xi Jinping in October and September 2013, respectively, to accelerate and promote the interconnection and infrastructure between neighboring countries, as shown in Fig. 29.

The State Grid Corporation of Xinjiang will be combined with the energy resources and power supply demand. The State Grid will rely on long-distance, large capacity, low UHV loss technology to create the OBAOR economic belt transmission corridor, achieve interoperability among surrounding countries, and turn Xinjiang's geographical advantages into economic advantages.

In the 13th Five-Year Plan, the State Grid Corporation and the Autonomous Region Party Committee, through joint efforts from the government, will accelerate the construction of UHV power grid. The transmission line of two back lines $\pm 1100 \mathrm{kV}$ DC from Zhundong to Chengdu and Zhengzhou to Southern Anhui, North Hami to Chongqing $\pm 800 \mathrm{kV}$ DC started in 2015 , as shown in Fig. 30. These high-voltage and auxiliary power grid engineering will promote the sustainable development of Xinjiang electric power (Note 31, 32). 


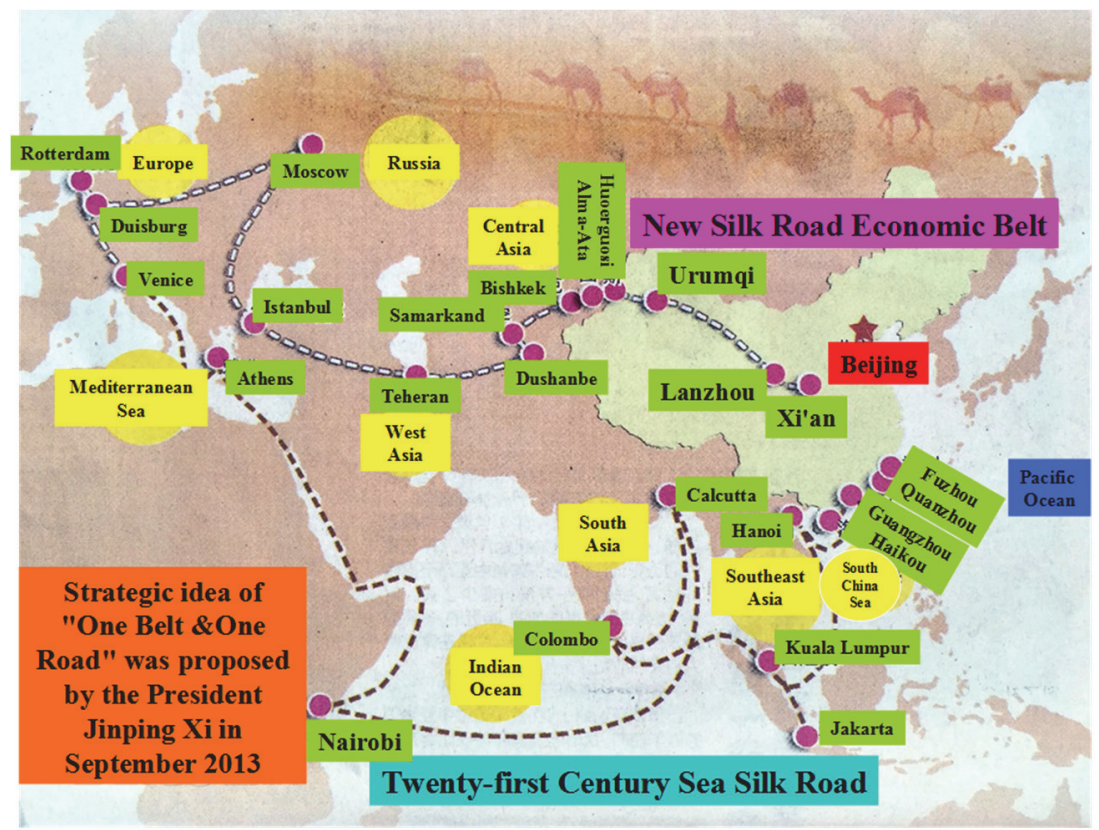

Figure 29. One Belt and One Road

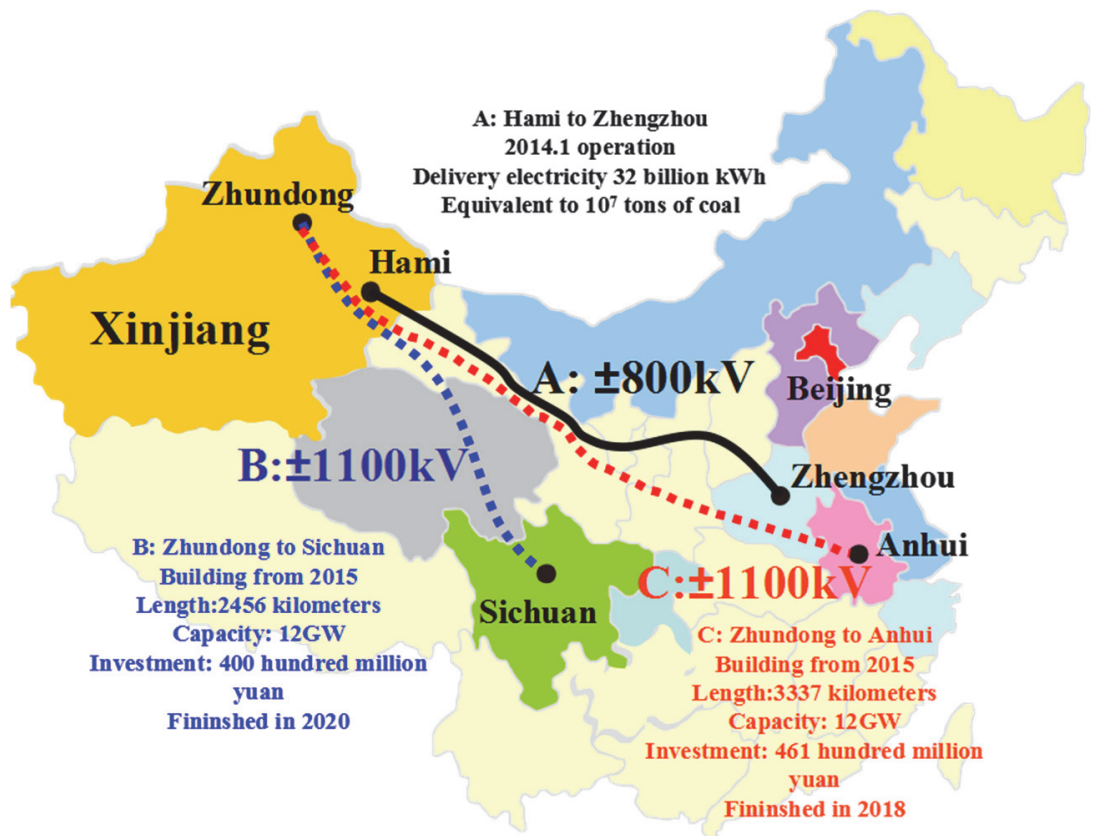

Figure 30. UHV power grid from Xinjiang

According to the Strategic Action Plan for Energy Development (2014-2020), which was recently issued by the Office of the State Council, and based on the news released by the government network on November 19, 2014, the total amount of controlled energy consumption by 2020 will be 4800000000 tons of standard coal and 4200000000 tons of controlled coal consumption. Non-fossil energy accounted for $15 \%$ of energy consumption; the proportion of natural gas reached $10 \%$ and that of coal consumption reached less than $62 \%$ (Note 32,33 ).

The targets listed in the Plan also include a relatively perfect energy security system by 2020. Primary energy production reached 42 tons of standard coal, energy self-sufficiency maintained at around $85 \%$, oil reserve production percentage of $14 \%-15 \%$, and a basically complete energy reserve for emergency systems. A unified, open, competitive, and orderly modern energy market should be established (Note 33,34 ). 
The seven important measures employed by the National Energy Bureau in 2015 are aimed at promoting energy production and consumption revolution, promoting energy transformation, and upgrading and building a safe, stable, diversified, clean, and modern energy system (Note 34).

\subsection{Analysis of Threat Factors}

\subsubsection{Population Quantity}

According to the estimate of the U.S. Central Intelligence Agency (Note 11), the world's total population reached 72.44 millions in July 2014. Table 25 lists the top 20 most populated countries; China remains the most populated country with a population of 13.56 million, which accounts for $18.7 \%$ of the world population (Note 35). Population intelligence is the focus of energy research because population growth has a direct impact on the size and composition of energy demand; population growth also has indirect effects on economic growth and development; thus, the number of population and economic situation has a great impact on energy utilization (Ramphul et al., 2015; Begum et al., 2015). The huge population of China will inevitably affect the sustainable development of the energy industry.

Table 25. Top 20 countries of the world's population

\begin{tabular}{llllll}
\hline Ranking & Country & Population quantity & Ranking & Country & Population quantity \\
\hline 1 & China & 1355692576 & 11 & Japan & 127103388 \\
2 & India & 1236344631 & 12 & Mexico & 120286655 \\
3 & EU & 511434812 & 13 & Philippines & 107688231 \\
4 & USA & 318892103 & 14 & Ethiopia & 96633458 \\
5 & Indonesia & 253609643 & 15 & Vietnam & 93421835 \\
6 & Brazil & 202656788 & 16 & Egypt & 86895099 \\
7 & Pakistan & 196174380 & 17 & Turkey & 81619392 \\
8 & Nigeria & 177155754 & 18 & Germany & 80996685 \\
9 & Bangladesh & 166280712 & 19 & Iran & 80840713 \\
10 & Russia & 142470272 & 20 & Congo & 77433744 \\
\hline
\end{tabular}

\subsubsection{GDP Per Capita}

GDP data are divided by the number of people per capita. As shown in Table 26, China's GDP per capita is below the world average, which ranks 80th worldwide. However, considerable progress has been observed from previous years. As shown in Table 26, China has been ranked in the 92nd and 94th spots, in 2014 in the 79th and 84th by the IMF and WB, respectively (Herranz-Loncán \& Peres-Cajías, 2016; Bergeaud et al., 2015).

Table 26. GDP per capita of main 10 countries in 2014

\begin{tabular}{llllll}
\hline IMF 2014 & & & \multicolumn{3}{l}{ World Bank 2014 } \\
\hline Ranking & Country & Dollars per capita & Ranking & Country & Dollars per capita \\
10 & USA & 54597 & 9 & USA & 53042 \\
$\mathbf{7 9}$ & China & $\mathbf{7 5 8 9}$ & $\mathbf{8 4}$ & China & $\mathbf{6 8 0 7}$ \\
26 & Japan & 36332 & 23 & Japan & 38634 \\
18 & Germany & 47590 & 18 & Germany & 46251 \\
19 & UK & 45653 & 22 & UK & 41781 \\
20 & France & 44538 & 20 & France & 42560 \\
60 & Brazil & 11604 & 62 & Brazil & 11208 \\
27 & Italy & 35823 & 27 & Italy & 35686 \\
143 & India & 1627 & 144 & India & 1498 \\
57 & Russia & 12926 & 51 & Russia & 14612 \\
World & & $\mathbf{1 0 8 7 6}$ & World & & $\mathbf{9 8 9 7}$ \\
\hline
\end{tabular}

\subsubsection{Human development index}

The human development index is a measure of the level of economic and social development of the UNDP, which began in 1990 (Note 36). The human development index measures the average achievement of a country in three basic aspects of human development: 
1. Health and longevity of life, as indicated by life expectancy at birth;

2. Knowledge, as indicated by adult literacy rate, as well as primary, secondary, and university comprehensive enrollment rate;

3. Decent living standards, as indicated by GDP per capita.

The human development index is divided into four categories, based on the 2014 Human Development Index Ranking (Júnior et al., 2015; Bean et al., 2015):

1. Highest human development index (1-49): Norway (1), United States (5), Japan (17), South Korea (15);

2. Higher human development index (50-102): Russia (57), Malaysia (62), Thailand (89), China (91);

3. Medium human development index (103-144): Turkmenistan (103), The Philippines (117), India (135);

4. Lower human development index (145-187): Angola (149), Sultan (166).

China ranks 91 st in the human development index, which is relatively backward.

\subsubsection{Global prosperity index}

An annual Global Prosperity Index ranking was launched by the Legatum Institute. The prosperity index includes wealth, economic growth, personal well-being, and quality of life. Compared with the annual rankings of 142 countries and regions in 2014, China ranked 54th, which was very low. These rankings are shown in Table 27.

Table 27. Global prosperity index in 2014

\begin{tabular}{|c|c|c|c|c|c|c|c|c|c|}
\hline \multirow[b]{2}{*}{$\begin{array}{l}\text { Ran } \\
k\end{array}$} & \multirow[b]{2}{*}{ Country } & \multicolumn{2}{|c|}{ Partial ranking } & \multirow[b]{2}{*}{$\begin{array}{l}\text { governme } \\
\text { nt } \\
\text { governanc } \\
\text { e }\end{array}$} & \multirow[b]{2}{*}{$\begin{array}{l}\text { Educatio } \\
\mathrm{n}\end{array}$} & \multirow[b]{2}{*}{$\begin{array}{l}\text { Health } \\
y\end{array}$} & \multirow[b]{2}{*}{$\begin{array}{l}\text { Security } \\
\text { \&securit } \\
\mathrm{y}\end{array}$} & \multirow[b]{2}{*}{$\begin{array}{l}\text { Person } \\
\text { al } \\
\text { freedo } \\
\mathrm{m}\end{array}$} & \multirow[b]{2}{*}{$\begin{array}{l}\text { Socia } \\
1 \\
\text { capita } \\
1\end{array}$} \\
\hline & & $\begin{array}{l}\text { Economi } \\
\text { c }\end{array}$ & $\begin{array}{l}\text { Entrepreneursh } \\
\text { ip \& } \\
\text { opportunity }\end{array}$ & & & & & & \\
\hline 1 & Norway & 3 & 7 & 7 & 5 & 5 & 6 & 2 & 1 \\
\hline 7 & $\begin{array}{l}\text { Australi } \\
\text { a }\end{array}$ & 12 & 13 & 9 & 1 & 14 & 16 & 3 & 6 \\
\hline 10 & U.S.A & 17 & 11 & 12 & 11 & 1 & 31 & 21 & 7 \\
\hline 13 & Britain & 28 & 8 & 10 & 20 & 19 & 21 & 10 & 12 \\
\hline 19 & Japan & 7 & 24 & 19 & 27 & 4 & 25 & 28 & 22 \\
\hline 54 & China & 6 & 65 & 66 & 61 & 58 & 63 & 117 & 24 \\
\hline 68 & Russia & 57 & 46 & 113 & 37 & 44 & 96 & 124 & 67 \\
\hline
\end{tabular}

\section{Conclusions}

China has massive primary and renewable energy resources. China's energy industry has undergone significant growth in the last decade. This research critically analyzes the development of China's energy industry by utilizing a SWOT approach. This research leads to a hierarchical structure of China's energy industry. The application of this evaluation framework highlights the SWOT factors associated with the Chinese energy industry. The performance and state of the energy industry in China was assessed through the hierarchical structure.

The results showed that the main strengths of the energy industry are generating capacity, nuclear energy power generation, renewable energy (hydropower, solar water heater, solar power generation, photovoltaic power generation capacity, wind power generation capacity, installed capacity of wind power, and bio-fuel), energy bases ( 5 comprehensive energy bases, 14 coal bases, 13 hydropower bases, and 8 photovoltaic power generation bases). China's international trade, urbanization, GDP, energy flow (waterway transportation, construction of LNG transport ships, the Central Asia-China gas pipeline, natural gas vehicles, length of oil and gas pipeline), UHV power grid, energy policy provide a number of development opportunities. The main weaknesses for development are $\mathrm{CO} 2$ emissions and primary energy issues (primary energy consumption structure in China, coal, Middle East crude oil import, natural gas sources, domestic natural gas, electric power production structure, new energy development issues). The threats to the sustainable development of China's energy industry are the number of population, GDP per capita, human development index, and global prosperity index. 
These findings provide valuable references to help China's energy industry improve its future competitiveness. These findings will also assist in the assessment of the sustainable development of the energy industry. These factors continually change in a dynamic social and market environment. Therefore, exploring these dynamics will be an ongoing study.

\section{Acknowledgements}

This study forms part of a research project supported by the Natural Science Foundation of China (Nos.51666017, 51667020, 51567022), the Natural Science Foundation of Xinjiang Uygur Autonomous Region (Nos.2016D01C062, 2017D01A026), the Xinjiang Uygur Autonomous Region Outstanding Youth Scientific and Technological Personnel Training Project (No.QN2016JQ0288), and the Xinjiang University Doctoral Foundation Project (No.2017XJUD068). The authors would like to express their gratitude for the support of these funding authorities.

\section{References}

Abrahams, L. S., Samaras, C., Griffin, W. M., \& Matthews, H. S. (2015). Life cycle greenhouse gas emissions from u.s. liquefied natural gas exports: implications for end uses. Environmental Science \& Technology, 49(5), 3237.

Ahlers, R., Budds, J., Joshi, D., Merme, V., \& Zwarteveen, M. (2015). Framing hydropower as green energy: assessing drivers, risks and tensions in the eastern himalayas. Earth System Dynamics, 6(1), 195-204.

Akal, M. (2015). A varx modelling of energy intensity interactions between china, the united states, japan and eu. Opec Energy Review, 39(1), 103-124.

Bean, L. M., Davis, M. A., Shah, N. R., Anderson, K. M., Workman, P. M., \& Kurnit, K. C., et al. (2015). National age standardized rate (asr) of ovarian cancer (oc) correlates with human development index (hdi): analysis of data from 165 countries. Gynecologic Oncology, 137(1), 192-192.

Begum, R. A., Sohag, K., Abdullah, S. M. S., \& Jaafar, M. (2015). Co 2, emissions, energy consumption, economic and population growth in malaysia. Renewable \& Sustainable Energy Reviews, 41(C), 594-601.

Bergeaud, A., Cette, G., \& Lecat, R. (2015). Gdp per capita in advanced countries over the 20th century. Remy Lecat.

Bonaiuto, M., Fornara, F., Ariccio, S., Cancellieri, U. G., \& Rahimi, L. (2015). Perceived residential environment quality indicators (preqis) relevance for un-habitat city prosperity index (CPI). Habitat International, 45, 53-63.

Chang, R. D., Zuo, J., Zhao, Z. Y., Zillante, G., Gan, X. L., \& Soebarto, V. (2017). Evolving theories of sustainability and firms: history, future directions and implications for renewable energy research. Renewable \& Sustainable Energy Reviews, 72, 48-56.

Chong, C. H., Ma, L., Li, Z., Ni, W., \& Song, S. (2015). Logarithmic mean divisia index (LMDI) decomposition of coal consumption in china based on the energy allocation diagram of coal flows. Energy, 85, 366-378.

Dent, C. M. (2015). China's renewable energy development: policy, industry and business perspectives. Asia Pacific Business Review, 21(1), 26-43.

Ding, N., Duan, J., Xue, S., Zeng, M., \& Shen, J. (2015). Overall review of peaking power in china: status quo, barriers and solutions. Renewable \& Sustainable Energy Reviews, 42, 503-516.

Dzonzi-Undi, J., \& Li, S. (2015). Swot analysis of safety and environmental regulation for china and usa: its effect and influence on sustainable development of the coal industry. Environmental Earth Sciences, 74(8), 6395-6406.

Erkko, A., \& Kun, F. (2015). Economic and political institutions and entry into formal and informal entrepreneurship. Asia Pacific Journal of Management, 32(1), 67-94.

Fan, X. C., Wang, W. Q., Shi, R. J., \& Li, F. T. (2015). Analysis and countermeasures of wind power curtailment in china. Renewable \& Sustainable Energy Reviews, 52, 1429-1436.

Goel, V., Slusky, M., Hoeve, W. J. V., Furman, K. C., \& Shao, Y. (2015). Constraint programming for lng ship scheduling and inventory management. European Journal of Operational Research, 241(3), 662-673.

Herranz-Loncán, A., \& Peres-Cajías, J. A. (2016). Tracing the reversal of fortune in the americas: bolivian gdp per capita since the mid-nineteenth century. Cliometrica, 10(1), 99-128.

Holz, C. A. (2013). The quality of china's gdp statistics . Social Science Electronic Publishing, 30(35), 309-338. 
Hong, C., Feiyu, Chen, Dandan, Zhu, Hui, Qi, \& Ruyin, Long. (2015). Burnout in chinese coal mine safety supervision. Energy Policy, 85, 22-31.

Hosenuzzaman, M., Rahim, N. A., Selvaraj, J., Hasanuzzaman, M., Malek, A. B. M. A., \& Nahar, A. (2015). Global prospects, progress, policies, and environmental impact of solar photovoltaic power generation. Renewable \& Sustainable Energy Reviews, 41, 284-297.

Hossain, M. S., Li, B., Chakraborty, S., Hossain, M. R., \& Rahman, M. T. (2015). A comparative analysis on china's energy issues and $\mathrm{CO}_{2}$ emissions in global perspectives. Sustainable Energy.

Hu, R., \& Zhang, Q. (2015). Study of a low-carbon production strategy in the metallurgical industry in china. Energy, 90, 1456-1467.

Hui, J., Cai, W., Wang, C., \& Ye, M. (2017). Analyzing the penetration barriers of clean generation technologies in china's power sector using a multi-region optimization model. Applied Energy, 185, 1809-1820.

Jaber, J. O., Elkarmi, F., Alasis, E., \& Kostas, A. (2015). Employment of renewable energy in jordan: current status, swot and problem analysis. Renewable \& Sustainable Energy Reviews, 49, 490-499.

Javaid, U., \& Rashid, A. (2015). Oil and gas potentials of central asian republics and relations with pakistan. South Asian Studies, 30(1), 127-148.

Jiang, S., Guo, J., Yang, C., Ding, Z., \& Tian, L. (2017). Analysis of the relative price in china's energy market for reducing the emissions from consumption. Energies, 10(5), 656.

Jiang, X., Zhu, K., \& Green, C. (2015). China's energy saving potential from the perspective of energy efficiency advantages of foreign-invested enterprises. Energy Economics, 49, 104-112.

Jie, W., Lin, L., Sun, J., \& Xiang, J. (2015). A comprehensive analysis of china's regional energy saving and emission reduction efficiency: from production and treatment perspectives. Energy Policy, 84, 166-176.

Jin, X., Zhang, Z., Shi, X., \& Ju, W. (2014). A review on wind power industry and corresponding insurance market in china: current status and challenges. Renewable \& Sustainable Energy Reviews, 38(5), 1069-1082.

Júnior, R. C. F., Belem, J. S., Andrade, F. O., Oliveira, M. R., Porto, J. M., \& Abreu, D. C. C. (2015). Influence of sex on gait under dual-task condition in elderly who live in a region with low human development index. Physiotherapy, 101, e408-e409.

Lee, N., Kim, J., Jang, C., Sung, Y., \& Jeong, H. (2014). Comparison of sensorless dimming control based on building modeling and solar power generation. Energy, 81, 15-20.

Lemoine, F., Poncet, S., \& Ünal, D. (2015). Spatial rebalancing and industrial convergence in china. China Economic Review, 34, 39-63.

Leopold, A. (2016). Energy related system dynamic models: a literature review. Central European Journal of Operations Research, 24(1), 231-261.

Li, C., Shi, H., Cao, Y., Wang, J., Kuang, Y., \& Tan, Y., et al. (2015). Comprehensive review of renewable energy curtailment and avoidance: a specific example in china. Renewable \& Sustainable Energy Reviews, 41, 1067-1079.

Li, K., \& Lin, B. (2015). How does administrative pricing affect energy consumption and $\mathrm{CO}_{2}$, emissions in china? Renewable \& Sustainable Energy Reviews, 42, 952-962.

Li, P., Hao, F., Guo, X., Zou, H., Yu, X., \& Wang, G. (2015). Processes involved in the origin and accumulation of hydrocarbon gases in the yuanba gas field, sichuan basin, southwest china. Marine \& Petroleum Geology, 59, 150-165.

Li, Y., Li, Y., Ji, P., \& Yang, J. (2015). The status quo analysis and policy suggestions on promoting china's hydropower development. Renewable \& Sustainable Energy Reviews, 51, 1071-1079.

Lin, B., \& Li, J. (2015). Analyzing cost of grid-connection of renewable energy development in china. Renewable \& Sustainable Energy Reviews, 50, 1373-1382.

Lin, B., Xu, L., Reviews, R. S. E., \& Kazmerski, L. (2015). Energy conservation of electrolytic aluminum industry in china. Renewable \& Sustainable Energy Reviews, 43, 676-686.

Liu, J. P., Yang, Q. R., \& He, L. (2017). Total-factor energy efficiency (TFEE) evaluation on thermal power industry with dea, malmquist and multiple regression techniques. Energies, 10(7), 1039. 
Liu, X., \& Luan, H. (2015). A brief analysis of the circumstances of the current coal industry and its trends in china. International Journal of Mining \& Mineral Engineering, 6(1), 408-411.

Macdougall, A. H., \& Friedlingstein, P. (2015). The origin and limits of the near proportionality between climate warming and cumulative $\mathrm{CO}_{2}$ emissions. Journal of Climate, 28(10), 150311135632008.

Ming, Z., Ouyang, S., Hui, S., Ge, Y., \& Qian, Q. (2015). Overall review of distributed energy development in china: status quo, barriers and solutions. Renewable \& Sustainable Energy Reviews, 50, 1226-1238.

Ming, Z., Song, X., Ma, M., \& Zhu, X. (2013). New energy bases and sustainable development in china: a review. Renewable \& Sustainable Energy Reviews, 20(4), 169-185.

Paltsev, S., \& Zhang, D. (2015). Natural gas pricing reform in china: getting closer to a market system? Energy Policy, 86, 43-56.

Pei, W., Chen, Y., Sheng, K., Deng, W., Du, Y., \& Qi, Z., et al. (2015). Temporal-spatial analysis and improvement measures of chinese power system for wind power curtailment problem. Renewable \& Sustainable Energy Reviews, 49, 148-168.

Petroleum, B. (2015). BP Statistical Review of World Energy. London.

Qian, Chen, \& Xin, Lv. (2015). The extreme-value dependence between the crude oil price and chinese stock markets. International Review of Economics \& Finance, 39, 121-132.

Qiu, S., Ruth, M., \& Ghosh, S. (2015). Evacuated tube collectors: a notable driver behind the solar water heater industry in china. Renewable \& Sustainable Energy Reviews, 47, 580-588.

Ramphul, Ohlan. (2015). The impact of population density, energy consumption, economic growth and trade openness on co 2, emissions in india. Natural Hazards, 79(2), 1-20.

Sanchespereira, A., Lönnqvist, T., Gómez, M. F., Coelho, S. T., \& Tudeschini, L. G. (2015). Is natural gas a backup fuel against shortages of biogas or a threat to the swedish vision of pursuing a vehicle fleet independent of fossil fuels? Renewable Energy, 83, 1187-1199.

Sun, S., \& Anwar, S. (2015). R\&d status and the performance of domestic firms in china's coal mining industry. Energy Policy, 79, 99-103.

Sun, S., Liu, F., Xue, S., Zeng, M., \& Zeng, F. (2015). Review on wind power development in china: current situation and improvement strategies to realize future development. Renewable \& Sustainable Energy Reviews, 45, 589-599.

Szoplik, J. (2015). Forecasting of natural gas consumption with artificial neural networks. Energy, 85, 208-220.

Tang, Xu, McLellan, Benjamin, C., Snowden, \& Simon, et al. (2015). Sustainability, vol. 7, pages 5508-5520: dilemmas for china: energy, economy and environment. Sustainability, 7(5), 5508-5520.

Tessler, Z. D., Vörösmarty, C. J., Grossberg, M., Gladkova, I., Aizenman, H., \& Syvitski, J. P., et al. (2015). Environmental science. profiling risk and sustainability in coastal deltas of the world. Science, 349(6248), 638.

Wang, G., Li, P., Hao, F., Zou, H., \& Yu, X. (2015). Origin of dolomite in the third member of feixianguan formation (lower triassic) in the jiannan area, sichuan basin, china. Marine \& Petroleum Geology, 63, $127-141$.

Wang, Z. X., Zheng, H. H., Pei, L. L., \& Jin, T. (2017). Decomposition of the factors influencing export fluctuation in china's new energy industry based on a constant market share model. Energy Policy, 109, 22-35.

Warner, M. (2015). Transformation of china's energy sector: trends and challenges. Asia Pacific Business Review, 2l(1), 147-153.

Wu, Z., \& Sun, H. (2015). Behavior of chinese enterprises in evaluating wind power projects: A review based on survey. Renewable \& Sustainable Energy Reviews, 43, 133-142.

Xinhua. (2014). Li Keqiang chaired a new session of the National Energy Commission's first meeting. Retrieved from http://news.xinhuanet.com/photo/2014-04/20/c_126411441.htm

Yang, G., Wang, J., Shao, W., \& Wang, H. (2015). The relationship between china's coal resource development and water resource. Energy Procedia, 75(2), 2548-2555.

Zeng, M., Liu, X., Li, Y., \& Peng, L. (2014). Review of renewable energy investment and financing in china: 
status, mode, issues and countermeasures. Renewable \& Sustainable Energy Reviews, 31(2), 23-37.

Zhang, Q., Li, Z., Wang, G., \& Li, H. (2015). Study on the impacts of natural gas supply cost on gas flow and infrastructure deployment in china. Applied Energy, 162.

Zhang, Z. Y., \& Qiping. (2013). Study on the development mode of national power grid of china. Proceedings of the Csee, 33(7), 1-10.

Zhao, Xingang, Liu, Lu, Liu, Xiaomeng, Wang, Jieyu, \& Liu Pingkuo. (2012). A critical-analysis on the development of china hydropower. Renewable Energy, 44(4), 1-6.

Zhao, X. G., Feng, T. T., Ma, Y., Yang, Y. S., \& Pan, X. F. (2015). Analysis on investment strategies in china: the case of biomass direct combustion power generation sector. Renewable \& Sustainable Energy Reviews, 42, 760-772.

Zhou, K., \& Yang, S. (2015). A framework of service-oriented operation model of china's power system. Renewable \& Sustainable Energy Reviews, 50, 719-725.

Zhou, K., \& Yang, S. (2015). Demand side management in china: the context of china's power industry reform. Renewable \& Sustainable Energy Reviews, 47, 954-965.

Zhou, K., Yang, S., Shen, C., Ding, S., \& Sun, C. (2015). Energy conservation and emission reduction of china's electric power industry. Renewable \& Sustainable Energy Reviews, 45, 10-19.

\section{Notes}

Note 1. http://www.bp.com/zh_cn/china/reports-and-publications/bp_20351.html

Note 2. http://www.world-nuclear.org/Features/Climate-Change/Climate-Change-and-Nuclear-Energy

Note 3. http://www.ren21.net/resources/publications/

Note 4. http://zh.wikipedia.org/

Note 5. Global Wind Energy Council. (2005). Retrieved from http:/www.gwec.net/news/latest-news/

Note 6. Central People's Government of the People's Republic of China. (2013).

Note 7. http://www.nea.gov.cn/2012-11/05/c_131951302.htm

Note 8. http://www.360doc.com/content/10/1105/14/4234947_66838275.shtml.

Note 9. http://news.bjx.com.cn/html/20141226/576815.shtml

http://www.sd.xinhuanet.com/tpzx/2015-01/11/c_1113949968.htm

Note 10. http://ec.europa.eu/environment/index_en.htm.

Note 11. https://en.wikipedia.org/wiki/Netherlands_Environmental_Assessment_Agency.

Note 12. National bureau of statistics of the People's Republic of China. Retrieved from http://www.stats.gov.cn/tjsj/ndsj/

Note 13. http://www.fenglifadian.com/news/201509/19587_2.html

Note 14. http://www.nea.gov.cn/2015-07/28/c_134455530.htm

Note 15. http://www.ce.cn/xwzx/gnsz/gdxw/201509/07/t20150907_6411104.shtml

Note 16. http://guangfu.bjx.com.cn/news/20150817/653551.shtml

Note 17. http://www.un.org/en/index.html

Note 18. http://www.chinanews.com/gj/2014/07-11/6374707.shtml

Note 19. International Monetary Fund. (1945). Retrieved from http://www.imf.org/external/

Note 20. World bank. (1945). Retrieved from http://data.worldbank.org/

Note 21. http://www.goldmansachs.com/what-we-do/investing-and-lending/banking/

Note 22. https://www.cia.gov/library/publications/resources/the-world-factbook/wfbExt/region_eas.html.

Note 23. CIA World Factbook. (1947). Retrieved from

https://www.cia.gov/library/publications/resources/the-world-factbook/geos/ch.html

Note 24. http://www.lngtsg.com/h-nd-593-2_543.html 
Note 25. http://www.lngtsg.com/h-nd-582-2_543.html

Note 26. http://www.lngtsg.com/h-nd-560-7_562.html

Note 27. China associstion of the national shipbuilding industry. (1995.

Note 28. http://news.xinhuanet.com/expo/2014-11/20/c_127232810_5.htm

Note 29. China Petroleum Press. Retrieved from http://news.cnpc.com.cn/system/2014/11/18/001516264.shtml

Note 30. http://paper.people.com.cn/rmrb/html/2014-11/16/nw.D110000renmrb_20141116_7-03.htm

Note 31 .

http://baike.baidu.com/link?url=yes67zlxO-z86AUz0NDQPjv0vx0fPoB51eT-q5EmEFxUxoFn8tzvmFrBp345u mrGpZJSXuSyY7_PY12xCUCXya.

Note 32. http://money.163.com/14/1120/09/ABG00FEL00253B0H.html.

Note 33. http://www.gov.cn/zhengce/content/2014-11/19/content_9222.htm

Note 34. http://news.xinhuanet.com/fortune/2014-12/25/c_1113781212.htm

Note 35. https://www.cia.gov/index.html

Note 36. United Nations Development Programme. (1949). Retrieved from http:/www.undp.org/

\section{Copyrights}

Copyright for this article is retained by the author(s), with first publication rights granted to the journal.

This is an open-access article distributed under the terms and conditions of the Creative Commons Attribution license (http://creativecommons.org/licenses/by/4.0/). 